\title{
(مفهوم الحرية وأصولها في ضوء القرآن الكريم والسنة النبوية)
}

\section{مي بنت محمد صالح ناقرو}

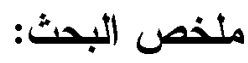

الحمد له رب العالمين، والصلاة و السلام على سيد الأنبياء والمرسلين، وعلى آله وصحبه

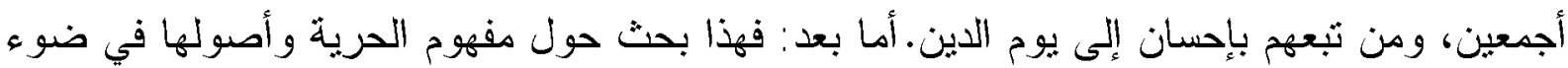

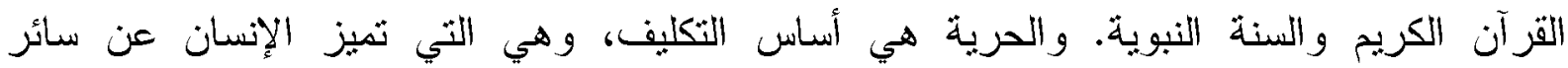
المخلوقات، فإذا فقدت الحرية ققدت الكر امة والإنسانية.

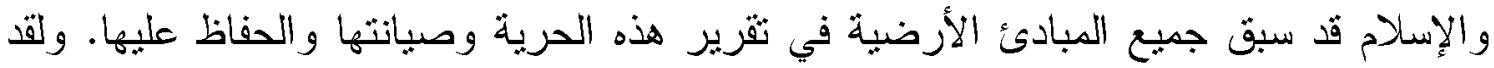

أكدت الباحثة أن الإنسان مكرم ومختار و لا مجال لإجباره على أب دين، بل هو مختار كما دلت على الإنى ذلك آيات قر آنبة كثيرة.

والحرية أباً كان نوعها اقتصادية، أو اجنماعية، أو غيرها لابد لها من أسس وضوابط وحدود

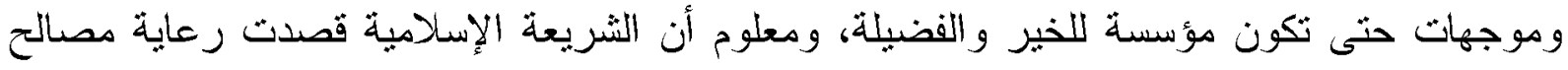

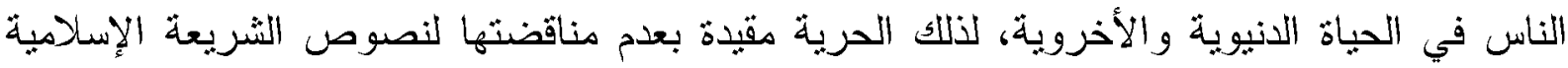
ومعارضتها، وعدم إحداث الضرر والفساد في الدتمع، وعدم الاعنداء على هصالح الآخرين وحرياتهم.

وقد استخدت الباحثة في هذا البحث المنهج الاستثرائي في استثراء وتثبع النصوص الثرعية من الكتاب و السنة فيما بتعلق بموضوع البحث.

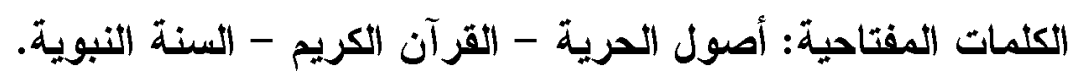

(The Concept of Freedom and its Origins in the Light of the Noble Qur'an and the Sunnah of the Prophet)

\section{Abstract:}

Praise be to God, Lord of the worlds, and prayers and peace be upon the master of the prophets and messengers, and upon his whole family and companions, and those who followed them with charity until the Day of Judgment. And yet: This is a research paper on the concept of freedom and its origins in the light of the Noble Qur'an and the Sunnah of the Prophet. Freedom is the basis of commissioning, and it is what distinguishes a person from other creatures.. If freedom is lost, dignity and humanity are lost.

And Islam has preceded all earthly principles in deciding, maintaining, and preserving this freedom. The researcher confirmed that the human being is honored and chosen and there is no room to compel him to any religion. Rather, he is chosen as indicated by many Quranic verses,

In this research, the researcher used the inductive method to extrapolate and follow Sharia texts from the Qur'an and Sunnah regarding the research topic.

And freedom, whatever its economic, social, or other kind, must have the foundations, controls, limits, and directives in order to be an institution for good 
and virtue, and it is known that Islamic Sharia intended to take care of people's interests in worldly and hereafter life, therefore freedom is restricted by not contradicting and opposing the provisions of Islamic Sharia, and not causing harm Corruption in society, and not attacking the interests and freedoms of others

Key words: Fundamentals of Freedom - The Noble Qur'an - The Prophetic Sunnah.

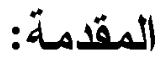

الحمد له رب العالمين، والصلاة والسلام على من أرسله الهه تعالى رحمة للعالمين. أما بعد؛ فإن

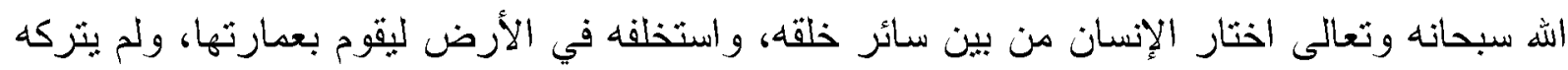

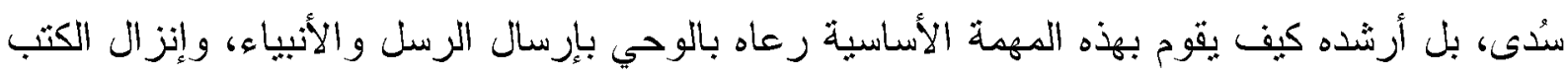
والصحف، وبيّن له الصراط المستقيم في الحقوق والواجبات، وكل هذا لنحقيق مصالح الناس.

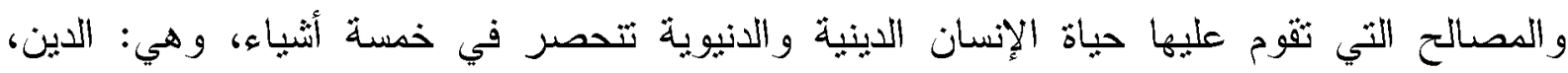
و النفس، والعقل، والعرض، والمال. وقد اتققت جميع الثرائع السماوية على مراعاة هذه الأنهان المصالح

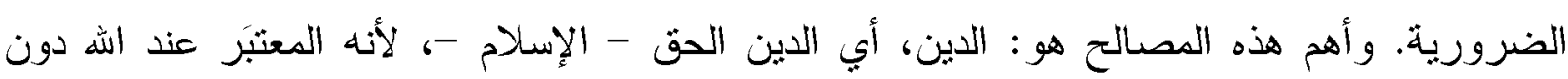
غيــره

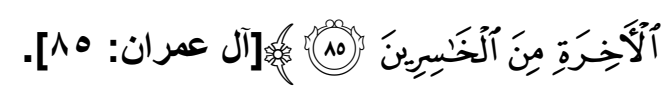
ولكن الهه نعالى بحكمثه منع إجبار الناس على الثباع هذا الدين الحق، أو إكراههم على الدخول

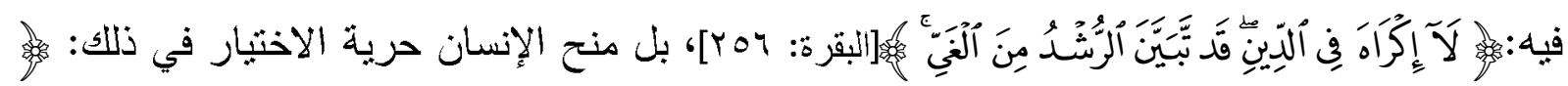

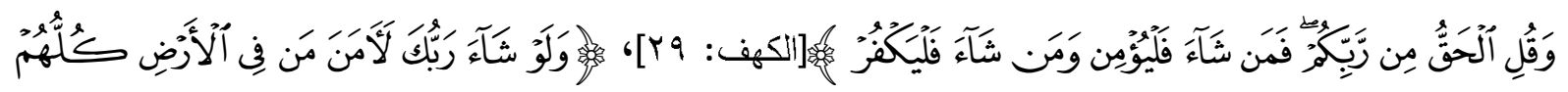

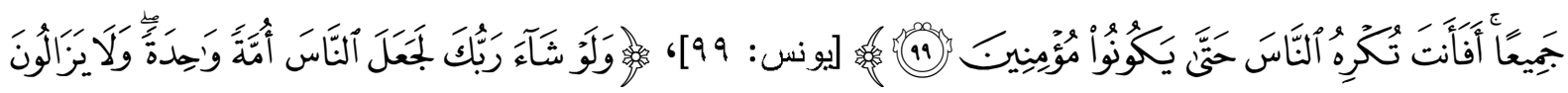

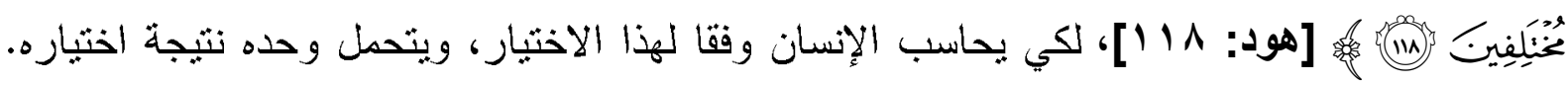

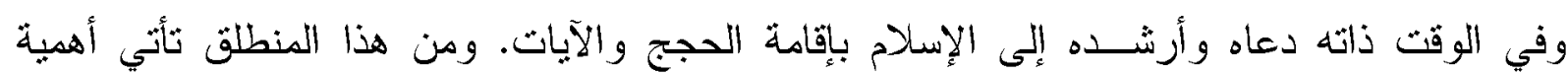
قضية مفهوم الحرية وأصولها في ضوء القرآ آن الكريم والسنة النبوية.

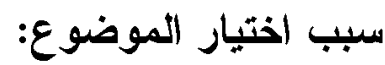
كان اختباري لهذا الموضوع (مفهوم الحرية وأصولها في ضوء القرآ آن الكريم والسنة النبوية)

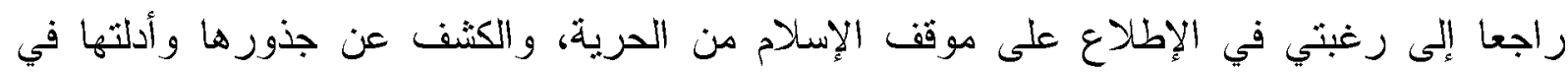

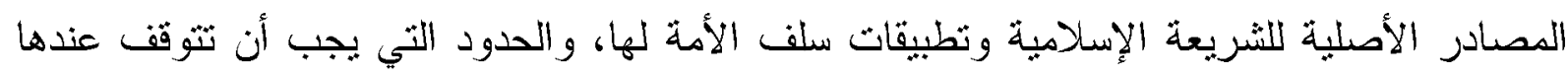
هذه الحرية، وقد كنت مُلمًّا ببعض جوانب هذا الموضوع لكن معرفتي به لم تكن تتجاوز معلومات

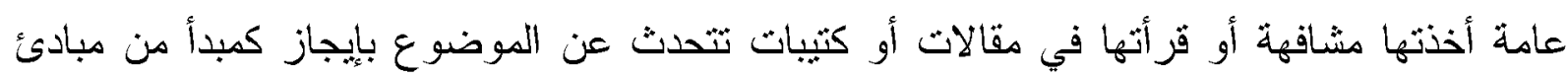
الإسلام العامة. 


\section{أهمية موضوع البحث:}

تأني أهمية دراسة هذا الموضوع من جوانب عدة، منها: من المكانة المهمة و الحساسة التي بحتلها العقل والتفكير في الثريعة الإسلامية وكونها الوسيلة الرئيسة لنكوين الرأي و إنتاج العلم و المعرفة، فالر أي ثمرة العقل والتفكير، ولا يخفى على من له أدنى اطلاع في القرآن الكريم ما جاء فيه من الأوامر والإشادات المنكررة بالعقل والتفكير ومدح أصحاب العقل وأولي الألباب. كما أن الاهنمام الو اسع للإسـام باللسان وبكل ما بتلفظ به من كلمات وعبار ات، واعثباره سببا رئيسا للإصصلاح والإقساد، ودخول الجنة أو النار، ودعلوم أن اللسان هو الوسيلة الرئيسة للتعبير عن الرأي، وتأني أهمبة اللسان من أهمبة ما يمكن أن بفعله، وما يؤديه من دور في حياة الإنسان سلبا أو إيجابا، و التعبير

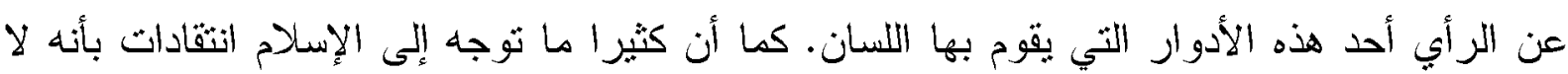
توجد فيه حرية التعبير عن الرأي، والصحيح هو إقرار حرية التعبير عن الرأي كحق هن حقوق الفرد في الشربعة الإسلامية مع مر اعاة الضو ابط الثر عية أثثاء ممارستها. منهج البحث: اتبعت الباحثة في هذا البحث على المنهج الاسثثرائي في اسثثراء ونتبع النصوص الثرعية من الكتاب والسنة فيما بتعلق بموضوع البحث، لاستخراج الآيات التي لها صلة بالموضوع ، ثم ثمث باستقراء الأحاديث النبوية الثريفة الثي ثتعلق بموضوع البحث، هذا فضدل عن الاستفادة من الكتب والبحوث الثي كثبث في الموضوع أو هي قريبة منه للعثور على الآيات والأحاديث ذات العلاقة بموضو عنا، فقد سهلت لي الأمر كثير ا. خطة البحث:

جاء البحث في مقدمة، ومبحثين وخاتمة: - المقدمة: وتتثل، سبب اختبار الموضوع، وأهمية موضوع البحث، ومنهج البحث. - المبحث الأول: معنى الحرية في اللغة وعند الققهاء. - المبحث الثاني: أصول الحرية في القرآن الكريم و السنة النبوية. - الخاتمة: وتثنمل النتائج الذي ثوصل إليها هذا البحت. 


\section{المبحث الأول: معنى الحرية في اللغة وفي الاصطلاح:}

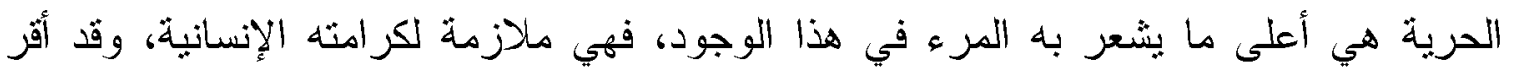

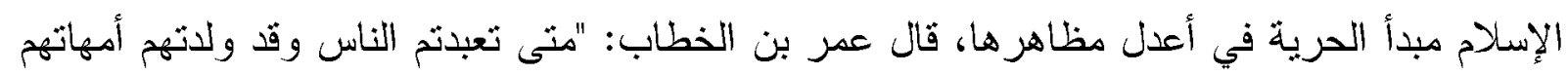

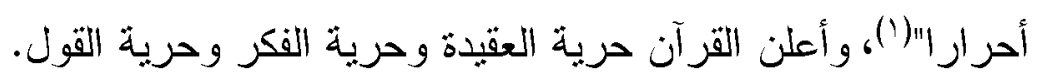

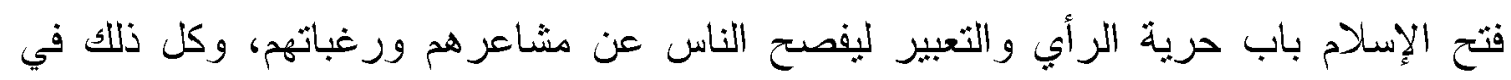
الإطار الذي حدده الإسلام للحرية، ولعل هذا واحداً من أسرار تكامل الدنهج الإسلادي. لئهي.

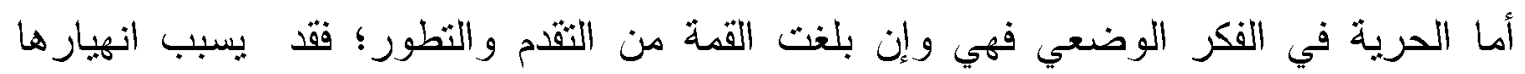

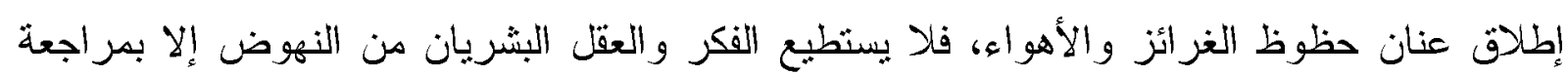

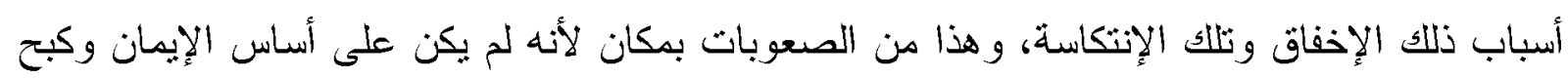

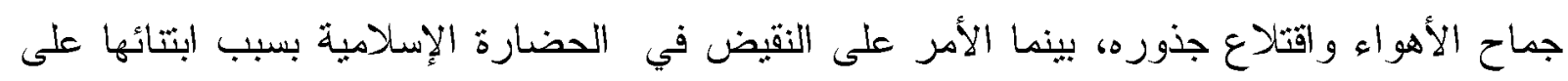

$$
\text { معنى الحرية في اللغة. }
$$

يعثبر لفظ (الحُرِيَّة) من الألفاظ الثي لها معان ودلالات عديدة، ولها استخدامات متعددة في اللغة

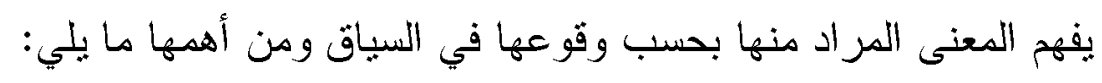

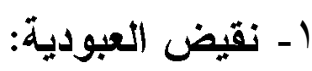

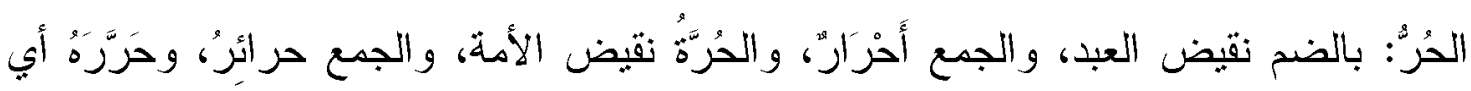

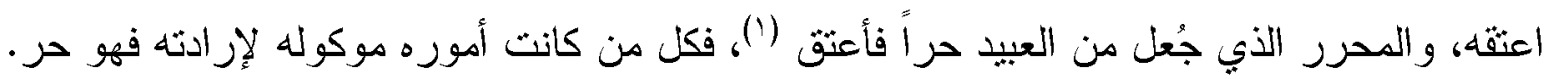

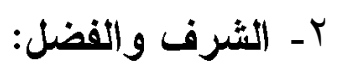

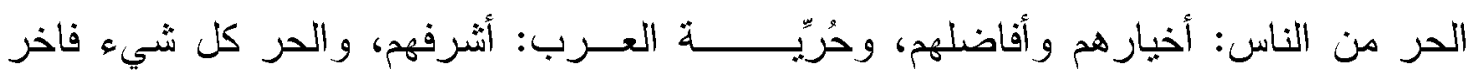

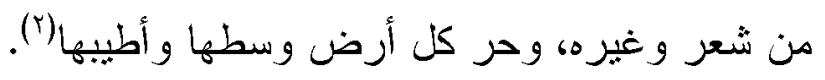

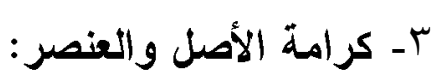
الحُرُ من الرجال: الكريم، والحُرَّة الكريمة من النساء(").

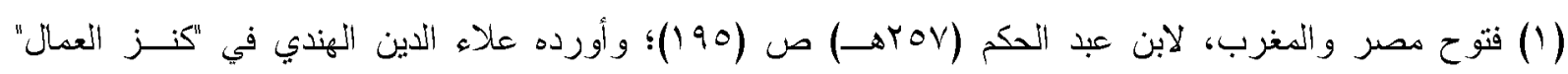
(1)

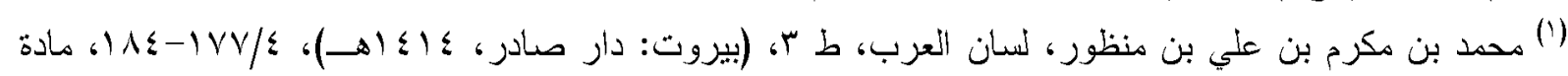
حرر.

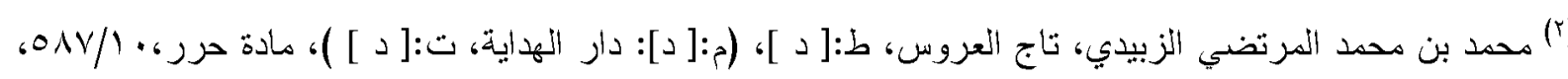

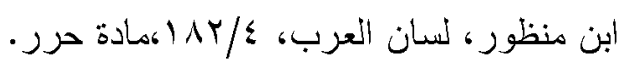


ع - الخظوص والصفاء و التثاء:

أبي الخلوص و البرايهة من الثُوائب ، أو العيب والنقص، ويسمى الرجل حُرَّاً لأنه خلُص من الرق

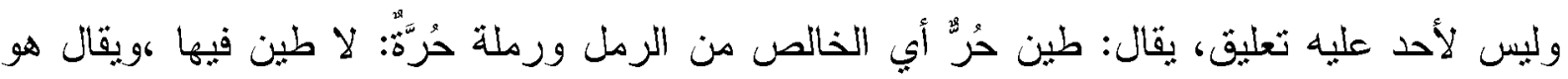

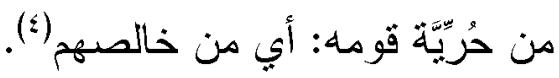

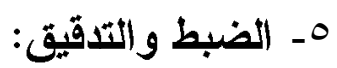

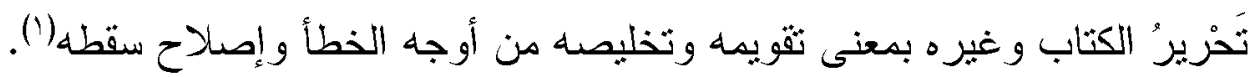

7- التوسط والاعتدال:

حر كل أرض وسطها وأطبيها، وحر الدار وسطها وخيرها (r).

وبالتأمل في معاني الحرية بلاحظ أنها تعني الخلوص من رث العبودية و العيب و النقص، و التحلي

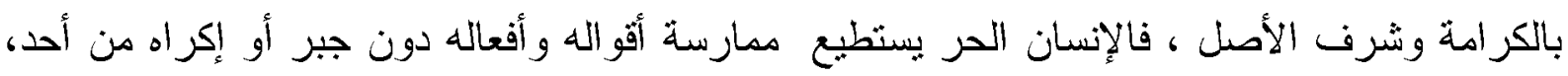

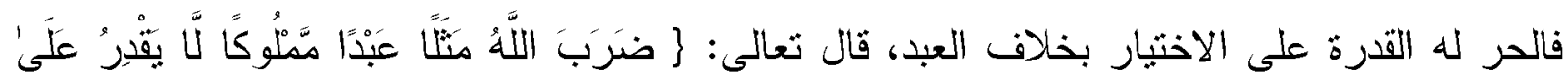

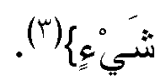

\section{• معنى الحرية اصطلاحاً:}

بالرجوع إلى القرآن الكريم والسنة النبوية نجد أن لفظ الحرية لم يرد صريحاً فيهما، وعدم ورود اللفظ لا بعني عدم ورود معنى ومفهوم الحرية، بل بالرجوع للنصوص القرآنية والنبوية، بُلحِظ الاهتمام بثقرير مفهوم ومصطلح الحرية اذ تعد الحرية من المبادئ والمعاني الأساسية التي قررها الإسلام، فقد وردت مشثقات الحرية في مو اضع مثعددة من ذلك:

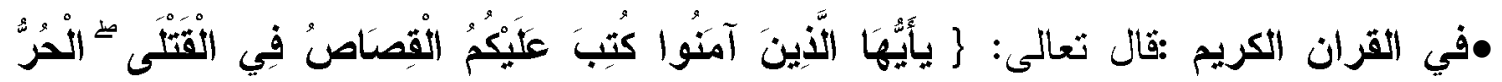

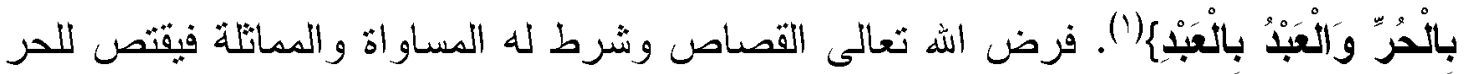

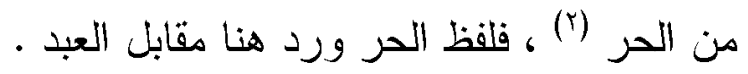

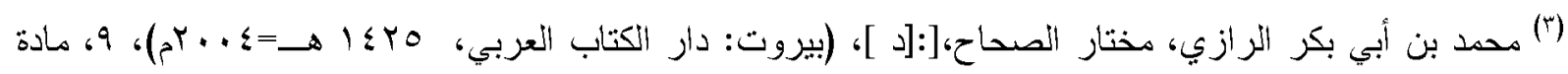

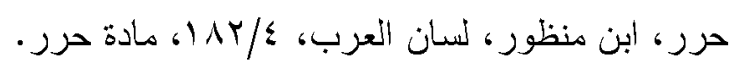

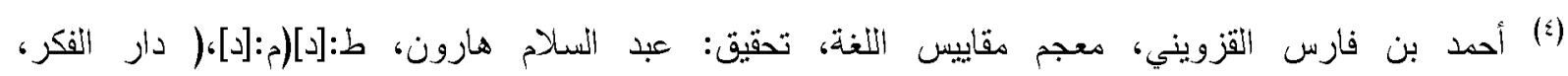

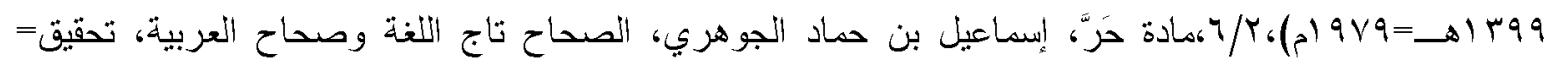

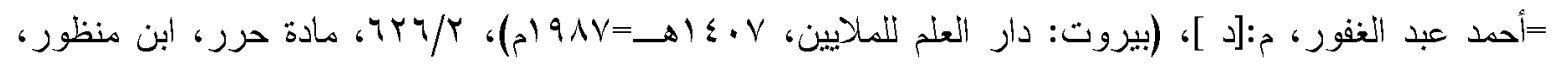

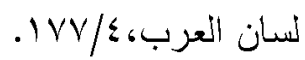

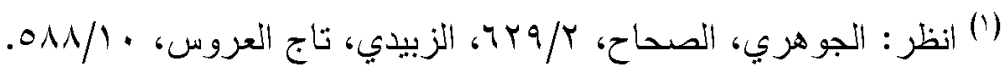

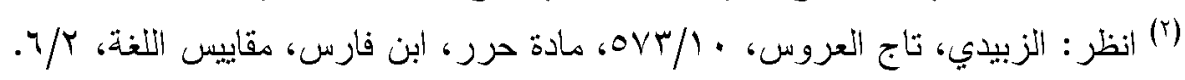

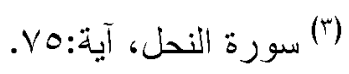

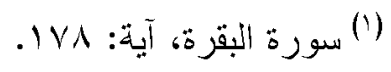




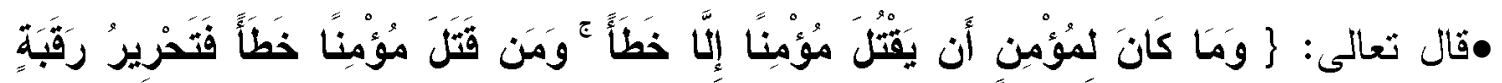

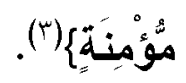

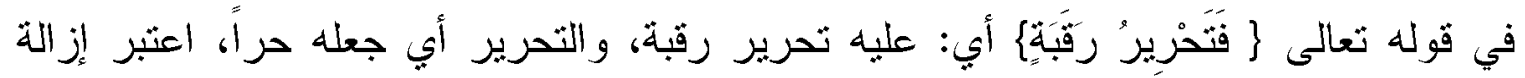

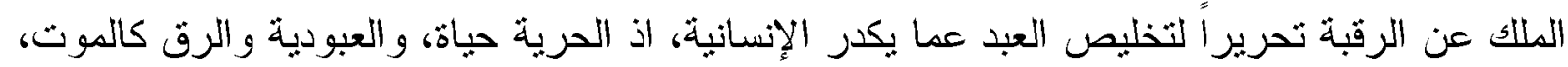

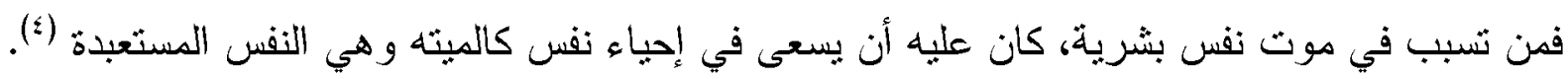

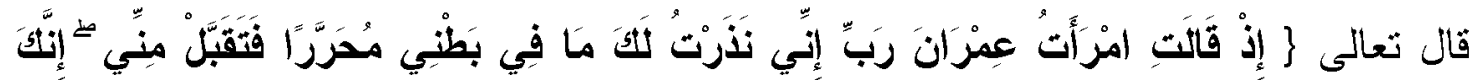

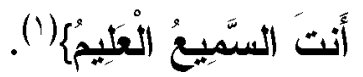

ورد عن المفسرين معنى محرراً بأن اللفظ مأخوذ من الحرية التي هي ضد العبودية، وهي ضربان:

$$
\text { أ- بأن لا يجري على الإنسان حكم السبي. }
$$

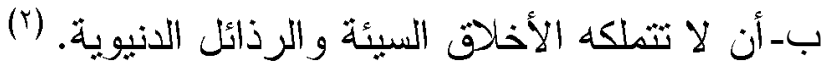

\section{• في السنة النبوية}

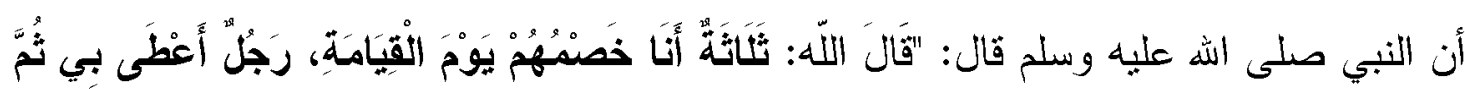

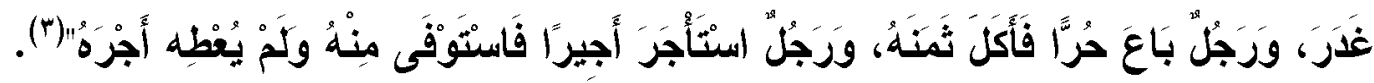

() الحسين بن محمد البغوي، معالم التتزيل في تفسير القر آن، تحقيق: عبد الزرزاق المهدي،(بيروت: دار إحباء التراث

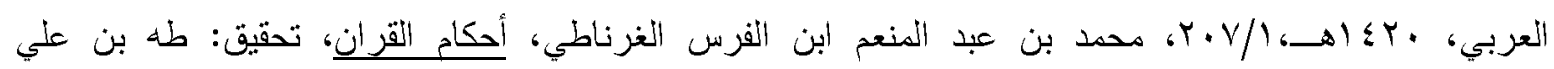

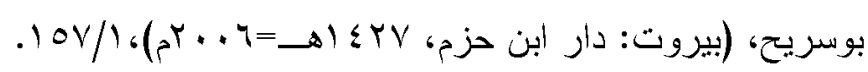

وقد اختلف الققهاء في حكم القصاص من الحر اذا قتل عبداً وهل بشترط التكافؤ بين القاتل والمقتول في الحرية :

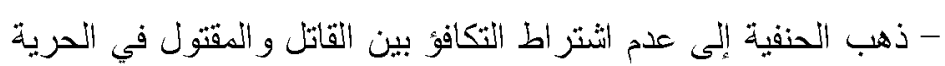
- ذهب الجمهور من المالكية و الثافعية والحنابلة إلى اثشتر اط التكافؤ بأن يكون المقتول مكافئًا للقاتل في الحرية فلا يقتل حر بعبد.

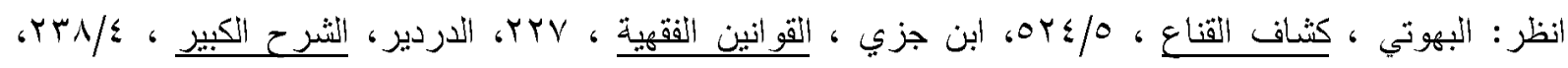

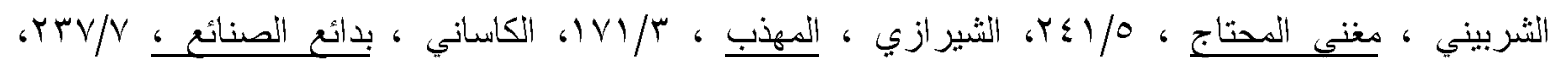

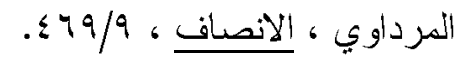

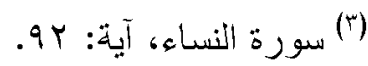

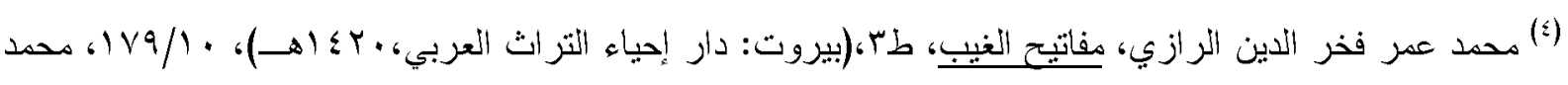

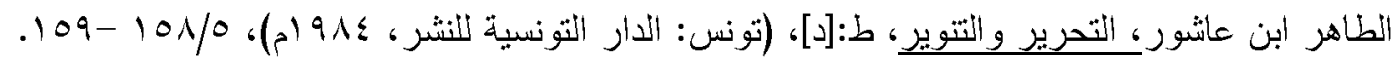

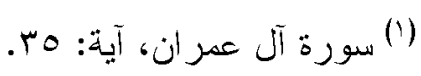

(r) محمد بن أحمد بن أبي بكر الترطبي، الجامع لاحكام القر ان، تحقيق: أحمد البردوني، إبر اهيم أطفيش، طب، (القاهرة:

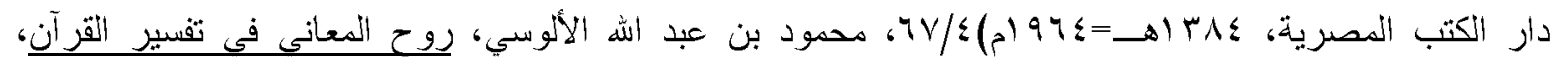

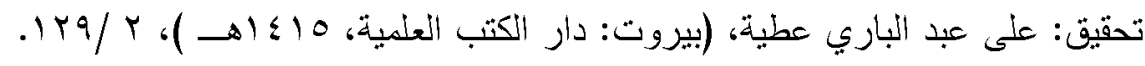


لفظ الحر ورد هنا مقابل العبد. هديث: " جاء رجل إلى النبي صلى الله عليه وسلم فقال: إن الآخر وقع على امرأته في

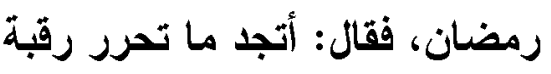
لفظ التحريز ورد بمعنى الاعتاق. وقد ذكر المعاصرون تعريفات الحرية ومنها:

\section{• • (التهانوي ('):}

الحرية شرعاً: "خلوص حكمي يظهر في الآدمي لانقطاع حق الغير عنه (r).

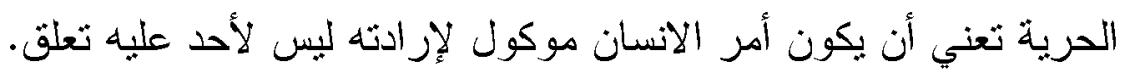

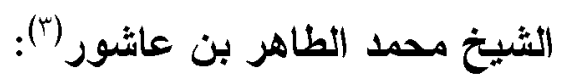
الحرية هي: " عمل الإنسان ما بقر على عمله حسب مشئيته لا ليصرفه عن عمله أحد غيره" (i)

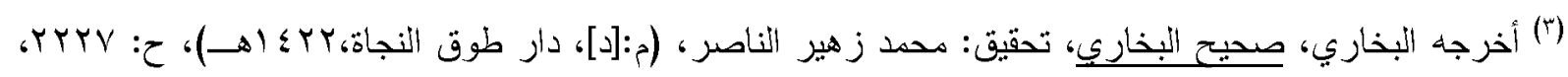

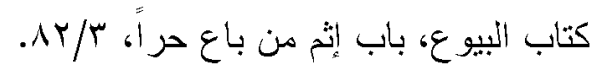

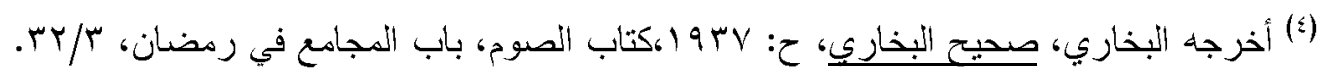

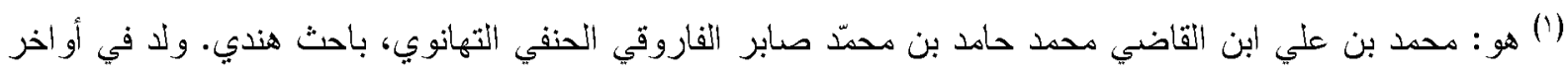

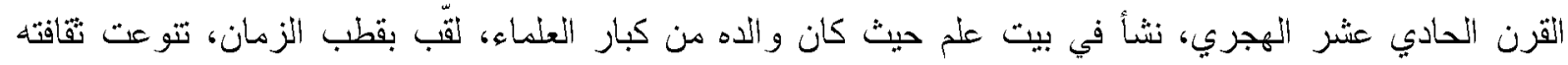

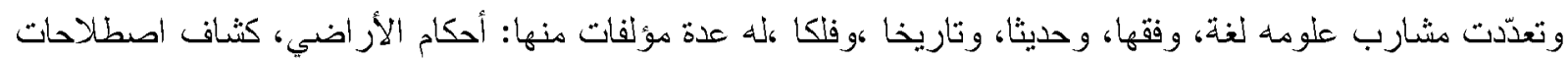

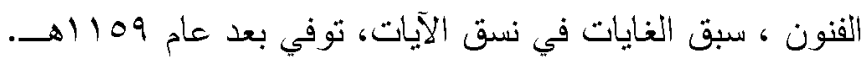

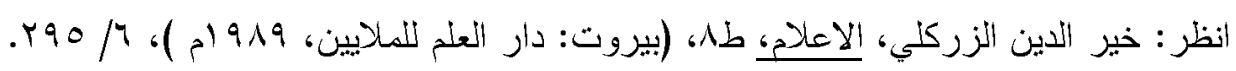

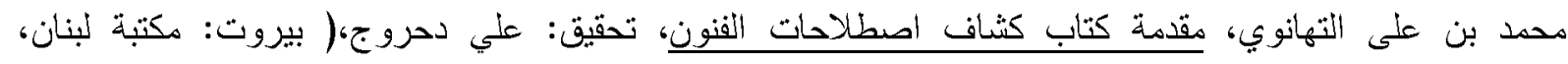

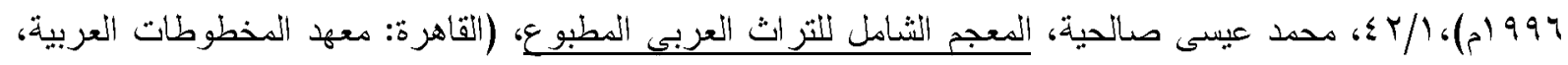
.

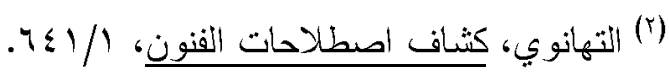

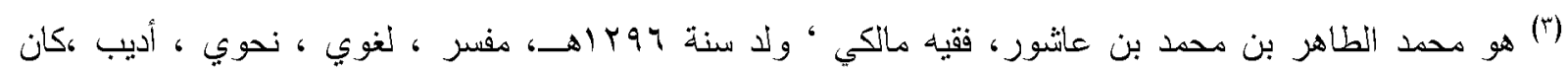

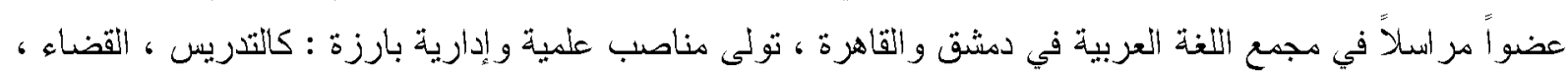
والافتاء ، وكان رئيس المفتين المالكين بتونس ، وشيخ جامع الزيتونة ، له مصنفات عديدة في علوم مختلفة ، منها:

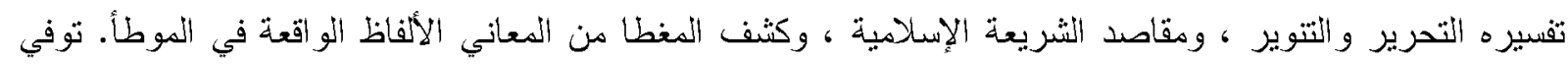

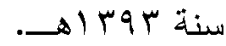

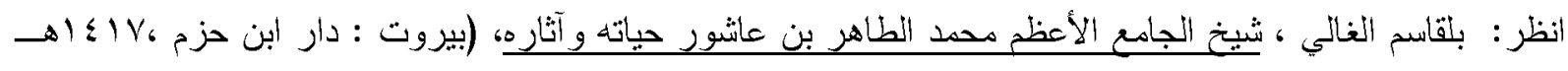

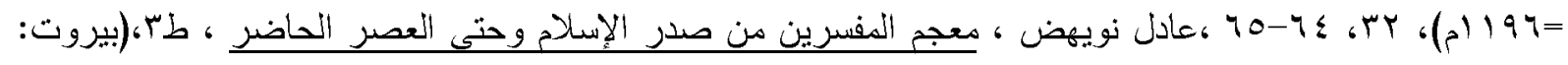

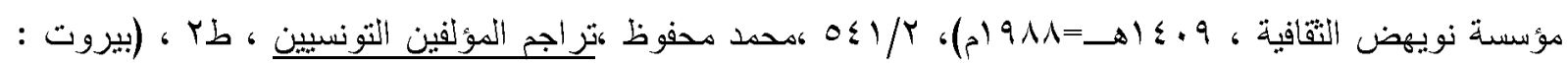

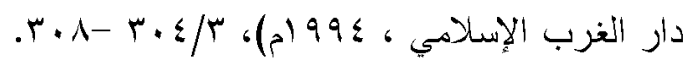




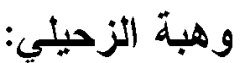

الحرية هي: "كل ما يميز الإنسان عن غبره ويثمكن بها من ممارسة أفعاله وأقواله وتصرفاته

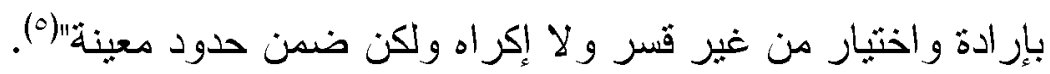

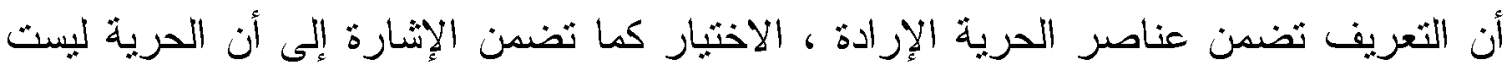
مطلقة بل لها ضوابط.

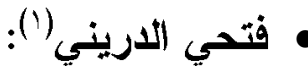

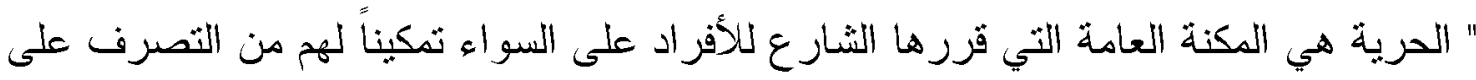

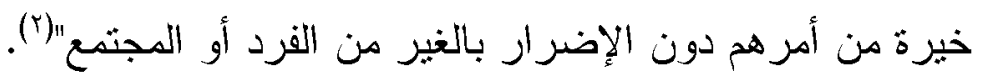

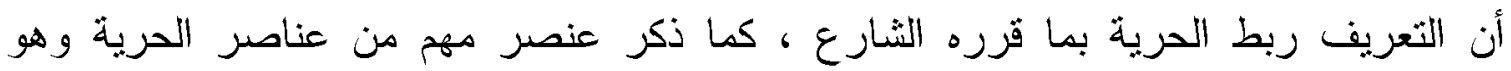
الاختبار ، وأثنار إلى ضابط عدم الاضرار بالآخرين.

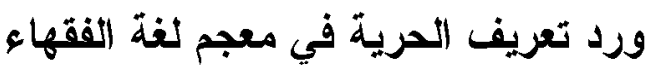

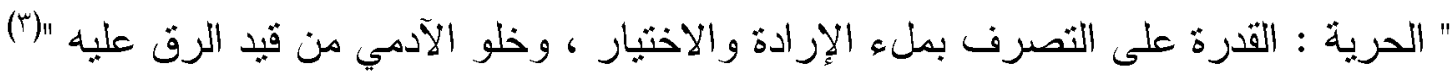

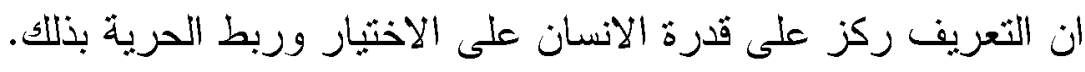

\section{• عرف محمد صادق الندوي الحرية بانها:}

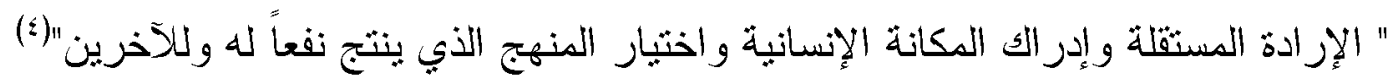

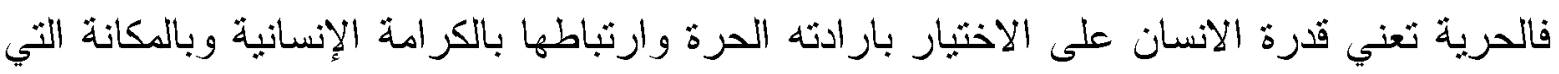
تمبز بها الانسان عن سائر المخلوقات وضبطها بما بحقق النفع للفرد والجماعة.

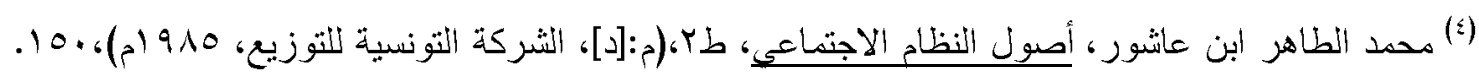

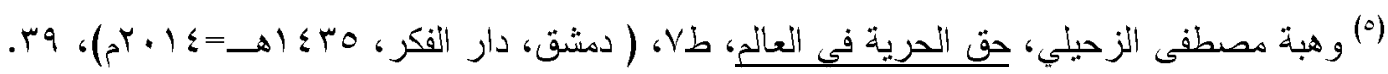

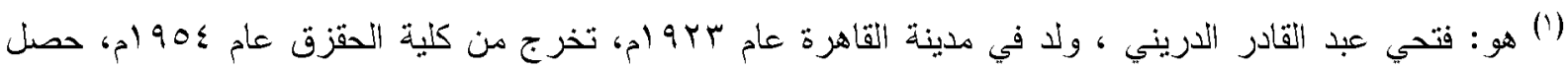

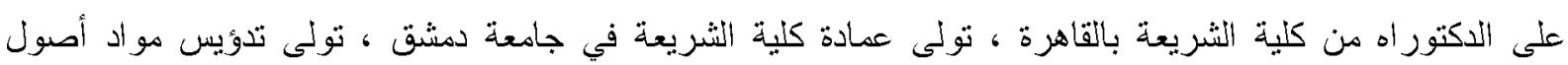

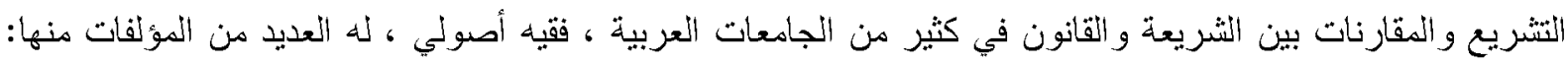

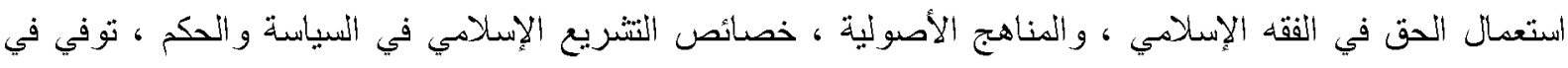
. $r \cdot 1 r / 4 / 1$

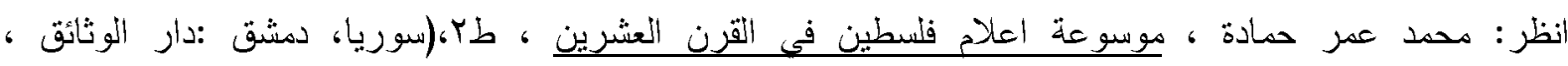

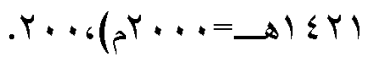

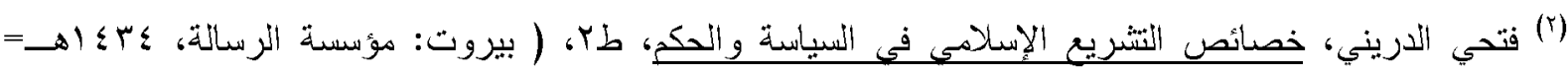
(r)

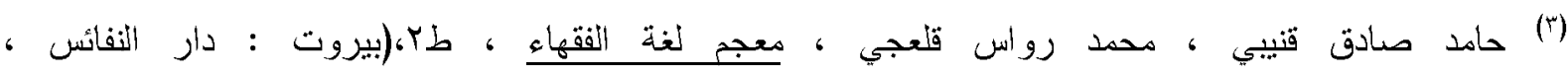

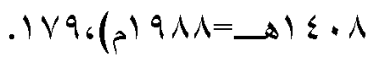

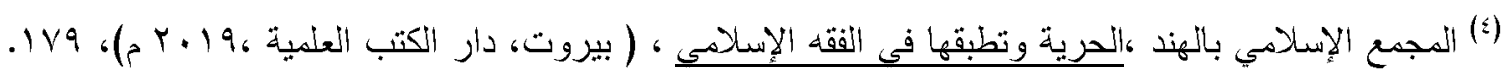




\section{ا التعريف المختار:}

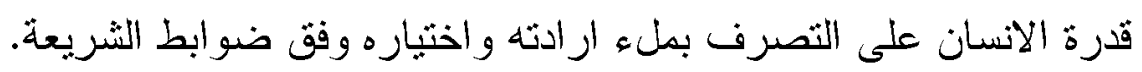

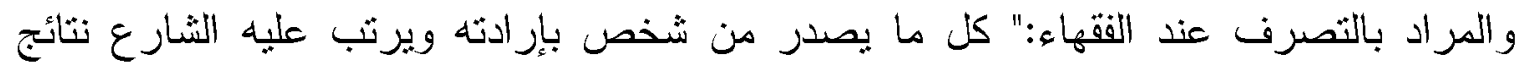

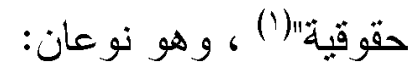

تصرف فعلي ويشمل الفعل أو نرك الفعل. تصرف قولي ويشكل القول وتزكه.

وقد قيد التصرف بالإرادة وهي: مجر القصد للفعل والاتجاه اليه (r).

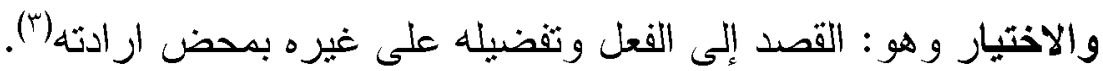

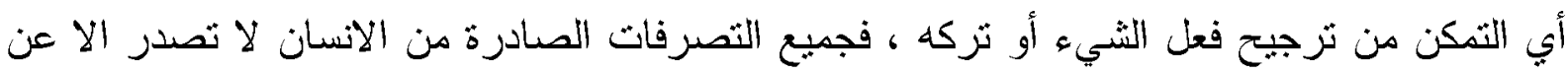

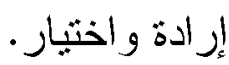

وضوابط الثريعة: قبدت الحرية في الثريعة الإسلامية بقيود عديدة منها :

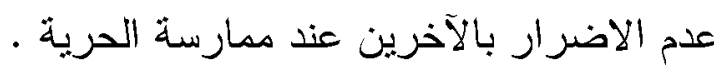

ان لا تفوت الحرية حقوقاً اعظم منها بالنظر إلى قيمتها ورنبتها ونتائجها.

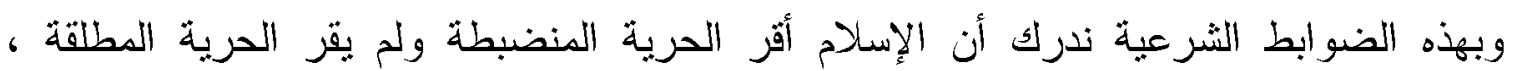

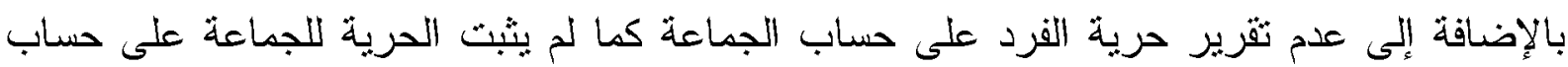

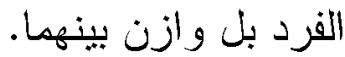

\section{الحرية في الإسلام تقوم عثى ثلاثة أسس رئيسة:} الأسساس الأول: هو إن اله خلق الإنسان وأعطاه الكرامة والشخصية هنذ أن خلقه وجعله خليفة في

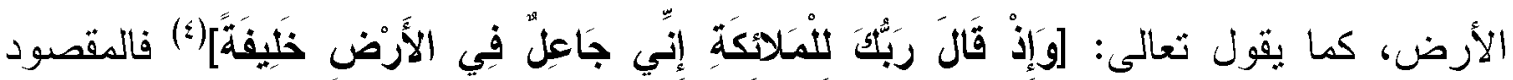

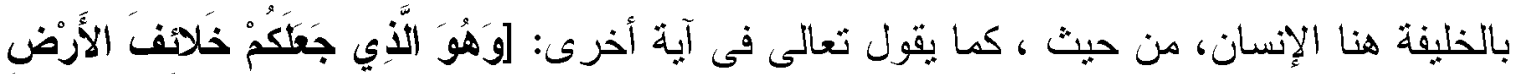

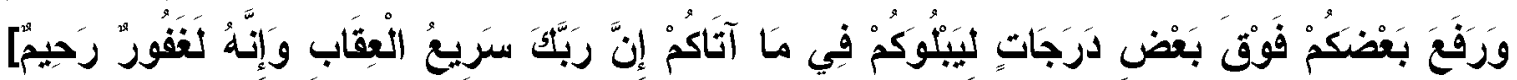

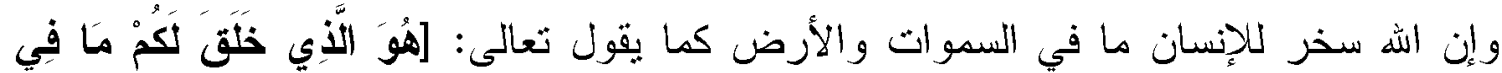

النْأَرْض جَمِيعاً

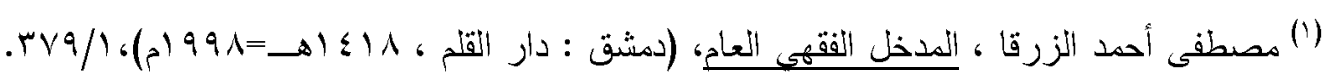

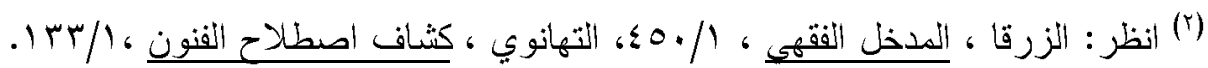

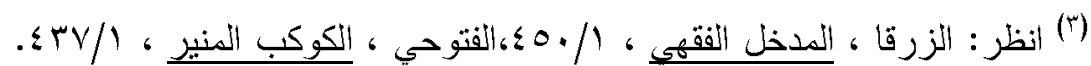

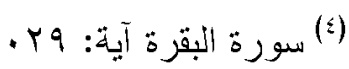

$$
\begin{aligned}
& \text { (1) (1) سورة الأنعام آية: }
\end{aligned}
$$

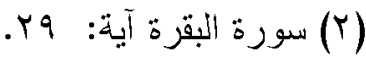




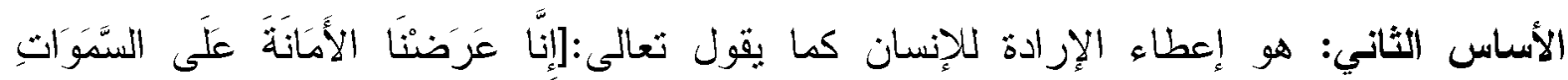

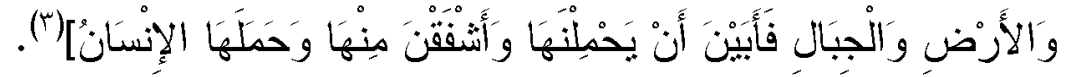

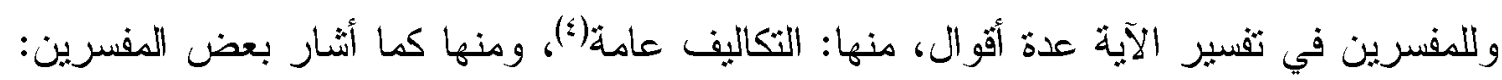

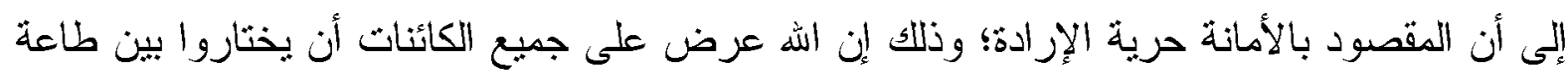

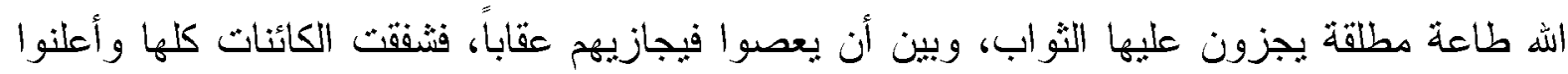

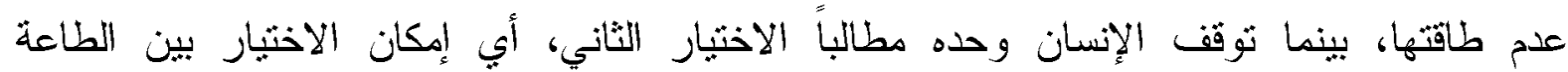

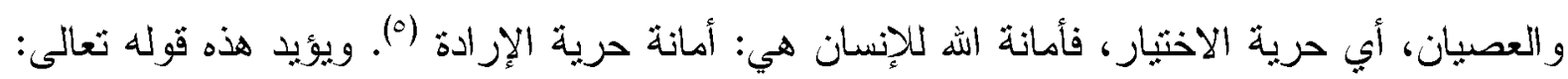

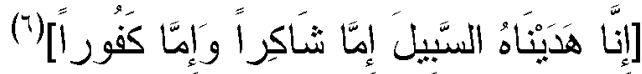

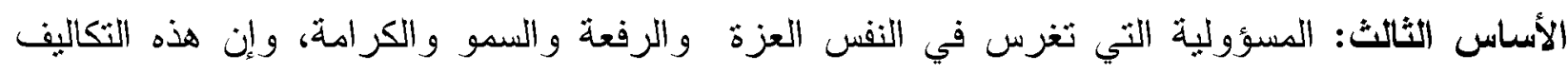

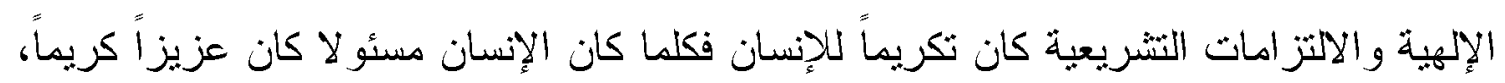

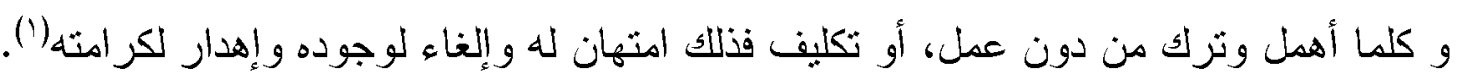

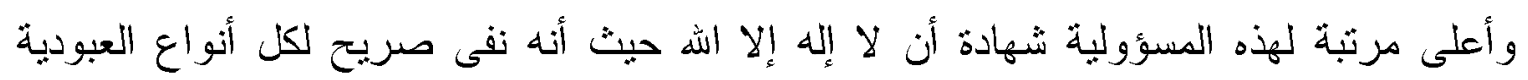

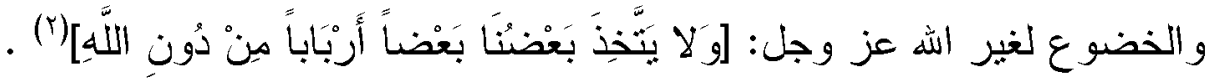

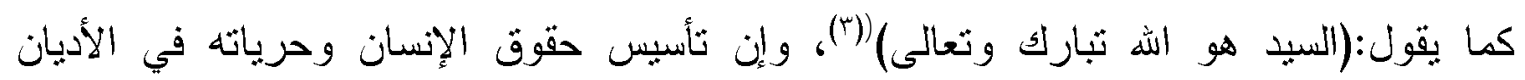

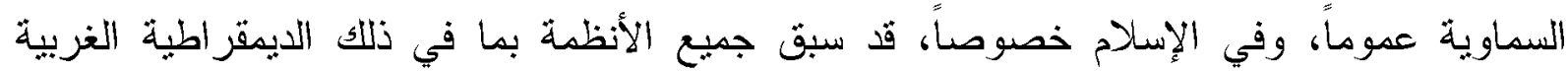

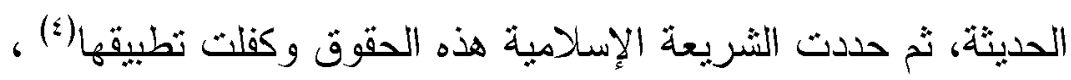

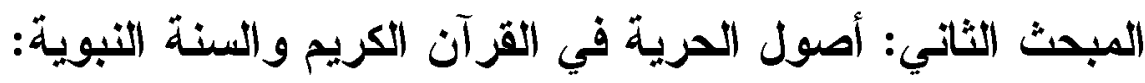
أولًا: أصول الحرية من القرآن الكريم:

تظهر مكانة الحرية في الإسلام بالنص عليها في القرآن الكريم المنزل على البشرية، ليكون

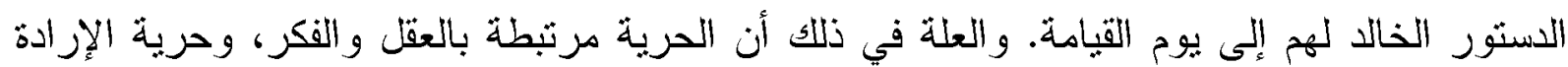

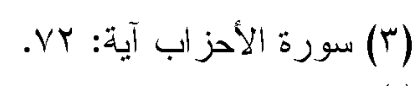

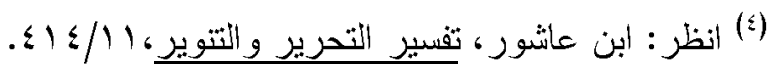

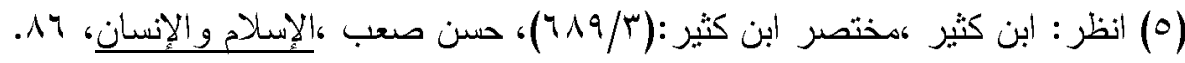

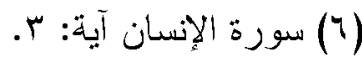

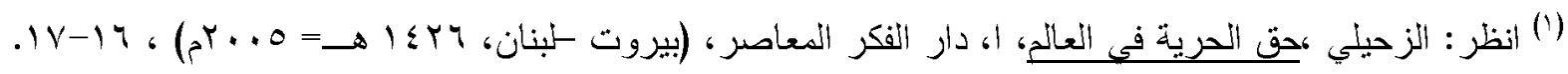

$$
\text { (") }
$$

(") أخرجه البخاري، في الأدب المفرد، تحقيق: محمد فؤاد عبد الباقي، باب هل يقول سيدي،طب ،(بيروت :دار البثائر

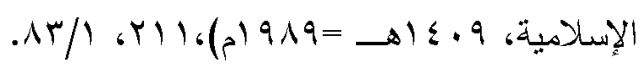

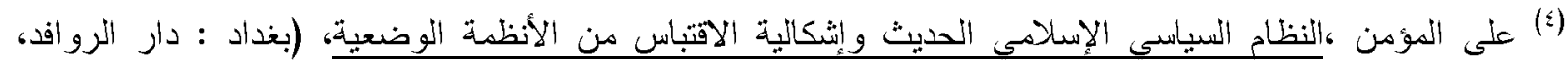

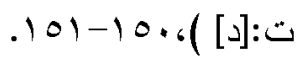


و الاختبار، و القناعة الذاتية للإنسان، تثصل بالعقيدة الثي تتبع من القلب، و لا سلطة لأحد عليها إلا له نعالى

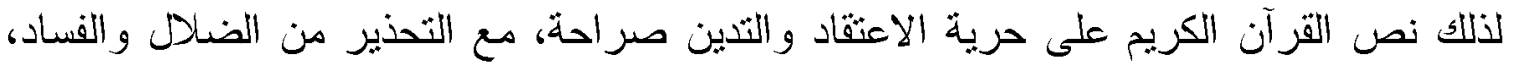

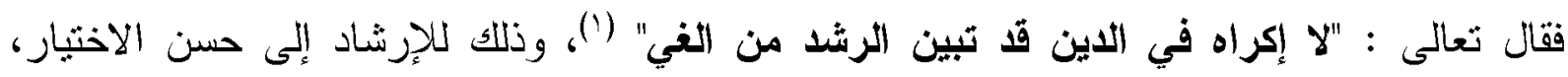

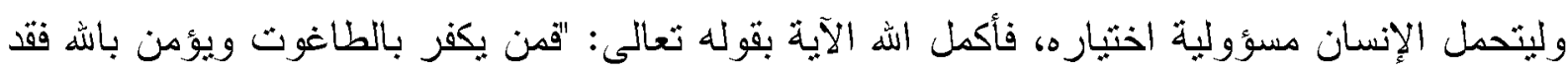

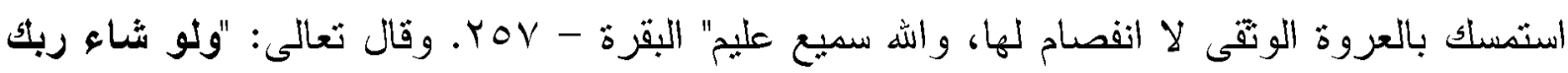
لآمن من في الأرض كلهم جميعا، أفأنت تكره الناس حتى يكون مؤمنين" (r) ، وذلك لأل الأن الإكراه

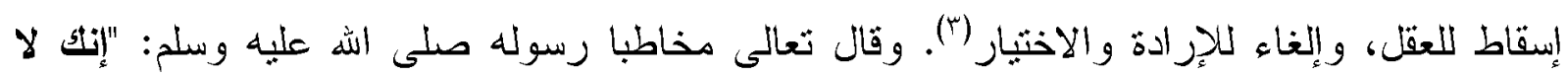

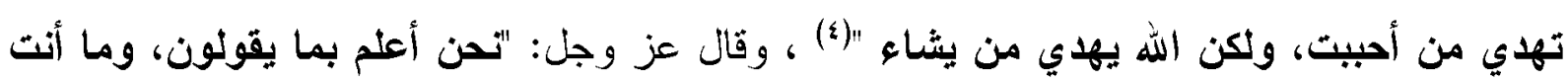

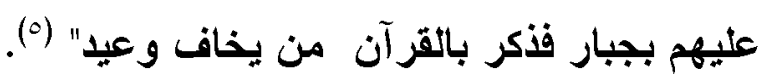

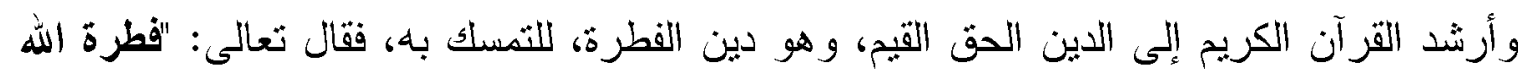

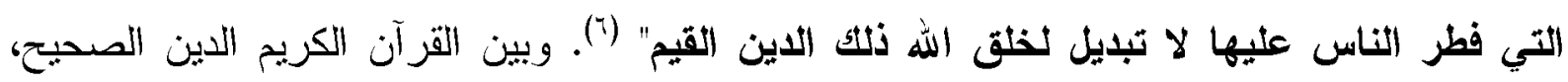
وثرك حرية الاختبار لمشيئة الإنسان، وهدد من أعرض عن الإنيل الإيمان الصحيح باله نعالى وبشريعته

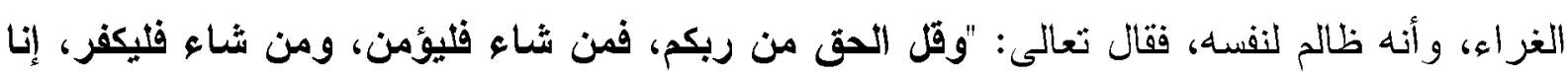

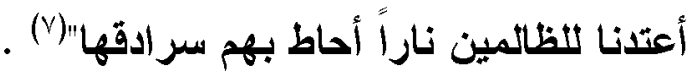
وقد سبق بيان أن مشتقات لفظ الحرية، ومثرادفاتها قد وردت في القرآن الكريم في أكثر من موضع '(')، ومن ذلك:

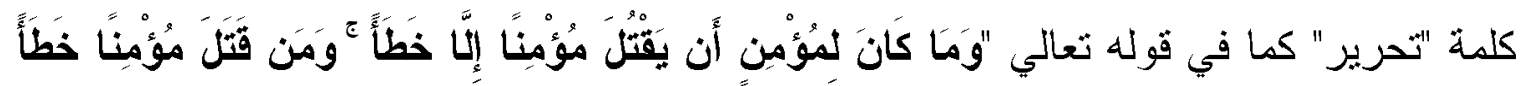

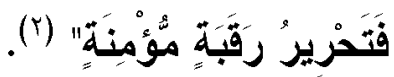

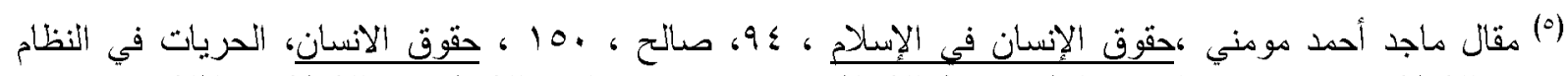

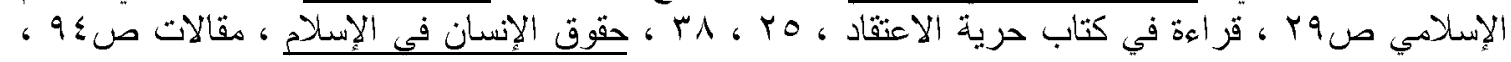

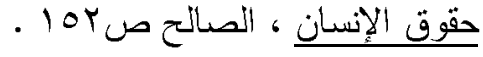

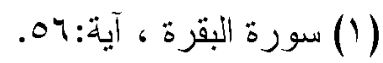
(Y) سورة بونس ، آية: (Y)

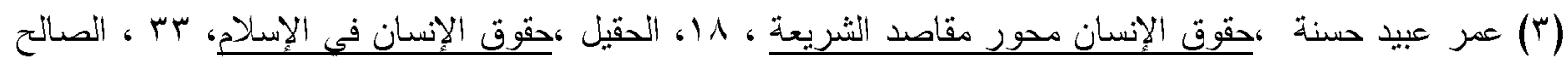

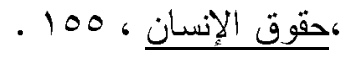

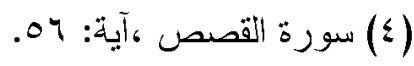
(1)

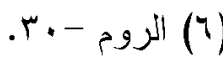
. rq: الكهف (V) (1) انظر : تعريف الحرية اصطلاحاً من البحث. 


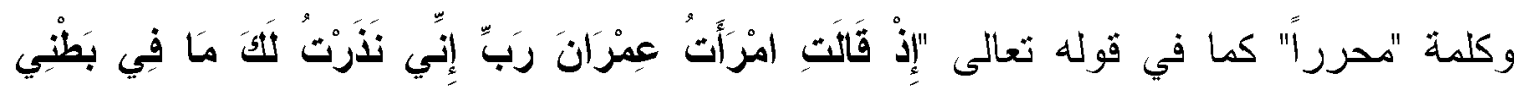

مُحَزَّرًا" (")

و على الرغم من عدم وجود كلمة الحرية في القرآن الكريم نصاً، إلا أن مفهوم الحرية ومعناها،

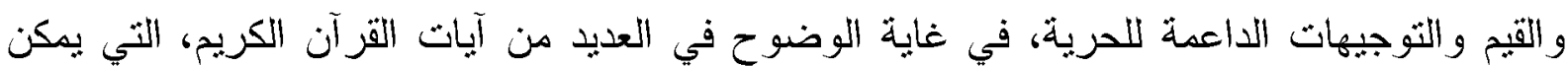
الاستشهاد ببعض منها:

أـالآيات الدالة على حرية المعتقد: حفل القرآن الكريم بالآيات التي ندل على حرية الاعتقاد، و لا

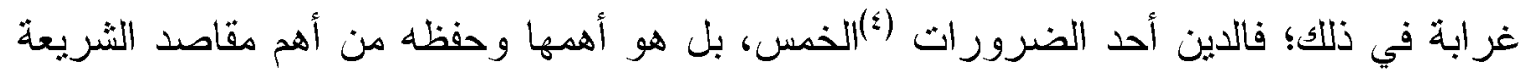

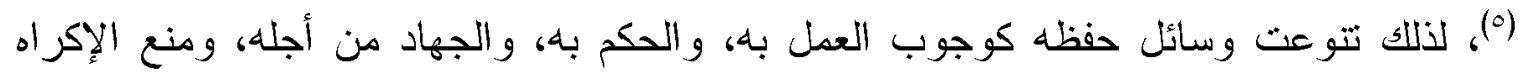
على الدين، فالفرد حر في اختيار عقيدنه،

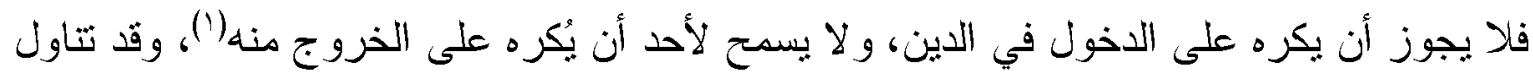

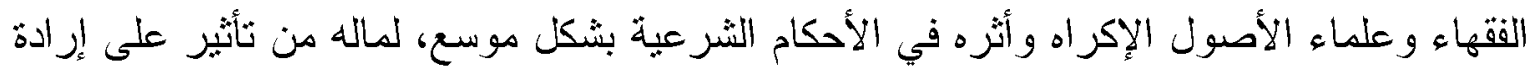
واختبار الإنسان.

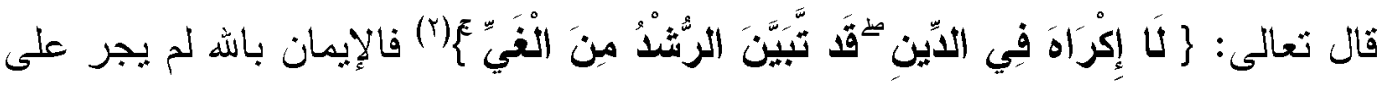

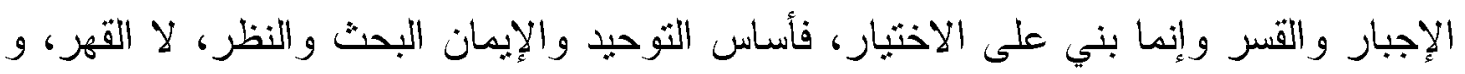

التقليد (").

$$
\begin{aligned}
& \text { (r) سورة النساء، آية: بr. }
\end{aligned}
$$

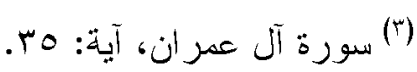

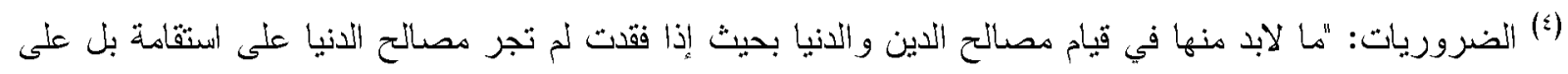

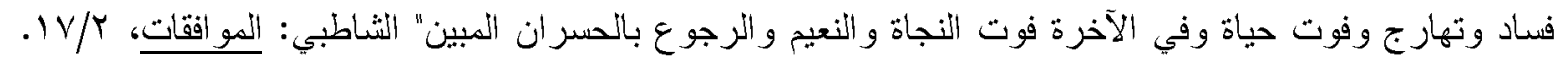

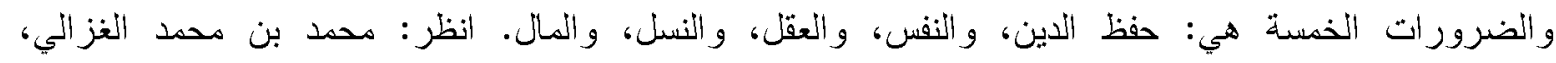

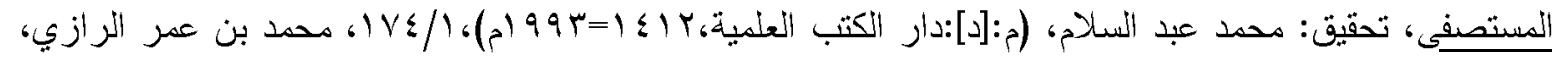

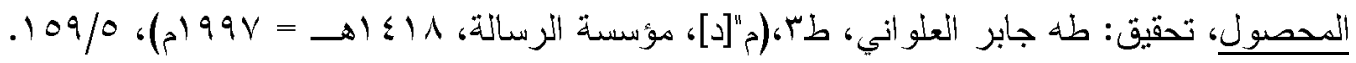

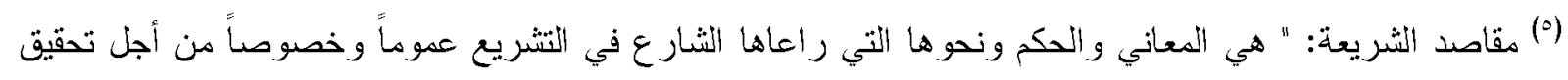

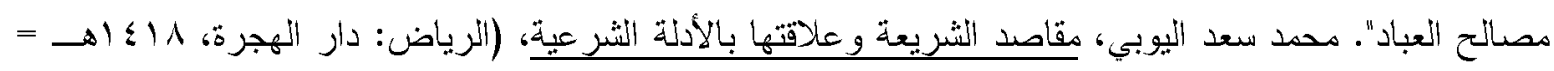

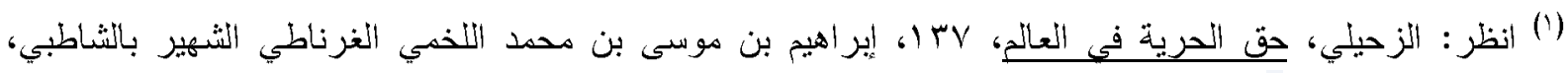

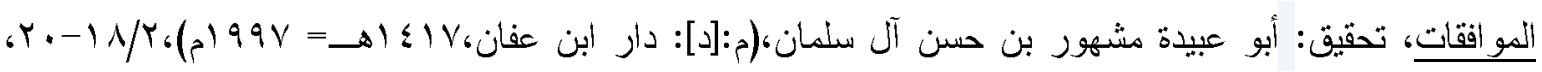

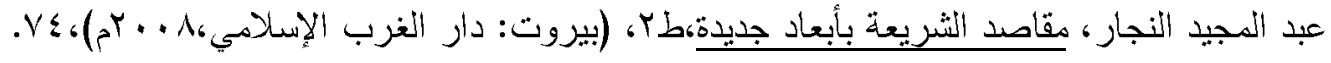

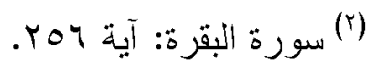
(") انظر: محمد بن أحمد الزمخرب، الكثاف عن حقائق غو امض التنزيل،طب،(بيروت:دار الكتاب العربي،

$$
\cdot r \cdot Y / l \cdot(-) \varepsilon \cdot V
$$


ب- الآيات الدالة على حرية الاختيار للى الإنسان، ومن ثم تقع عليه مسؤولية هذا الاختيار،

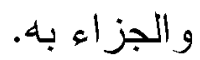

فالتكلف شرط في المسؤولية، وهو من المصطلدات التي استعملها علماء أصول الفقه للالالة

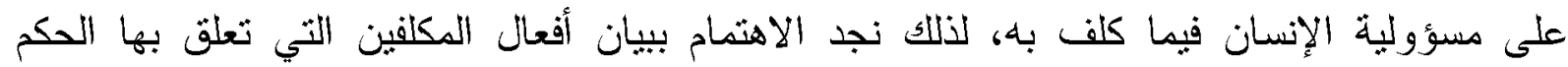
التكليفي، وشروط النكليف (๕)، ومن مستلزمات المسؤولية أن يمارس الإنسان حريثة الكاملة.

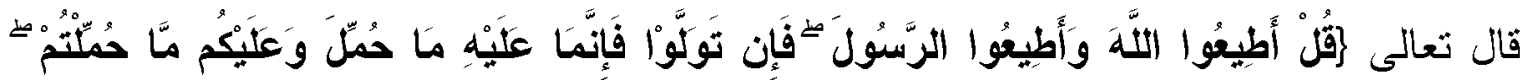

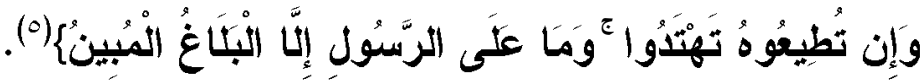

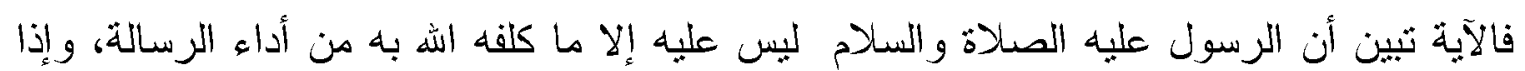

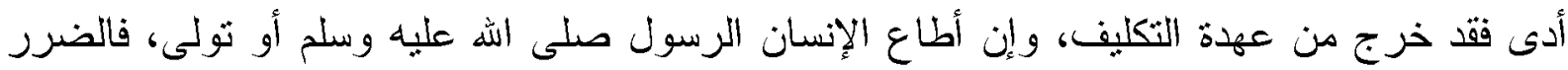

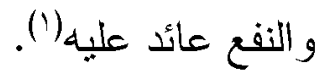

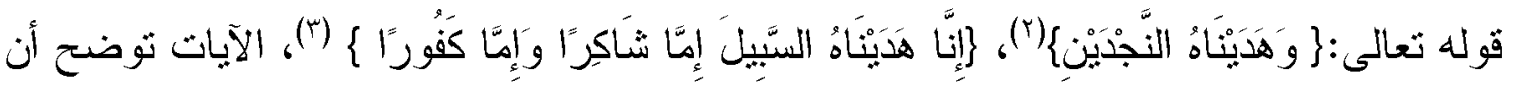

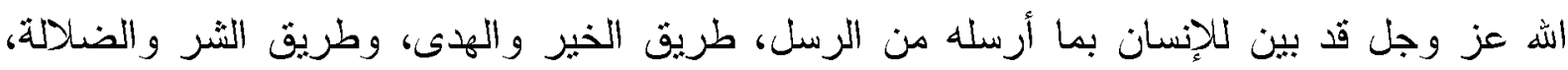

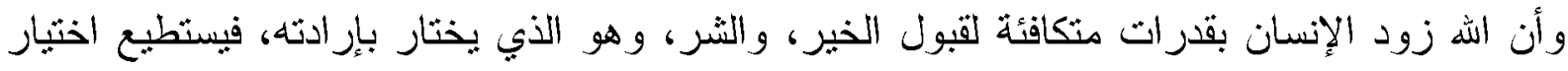

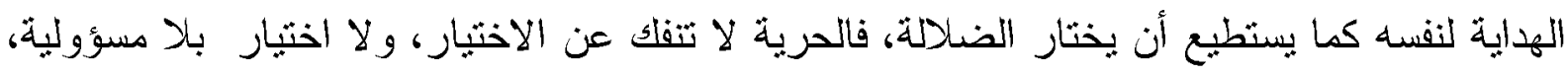

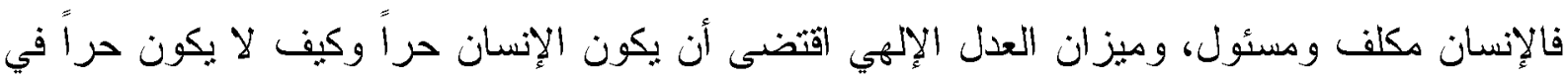

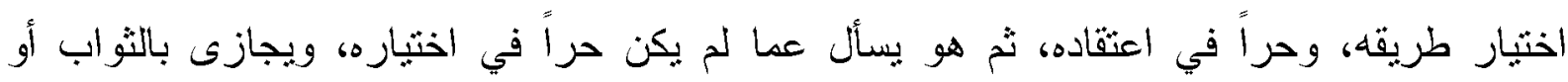
العقاب، الأمر الذب يتتافى مع العدل الإلهي.

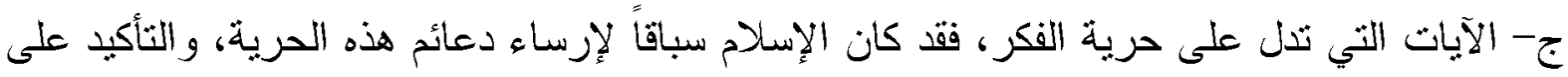

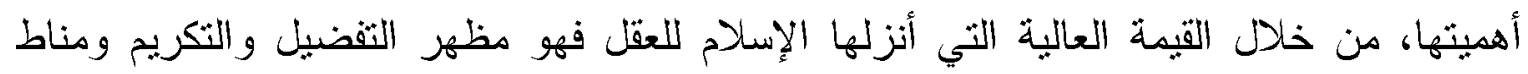

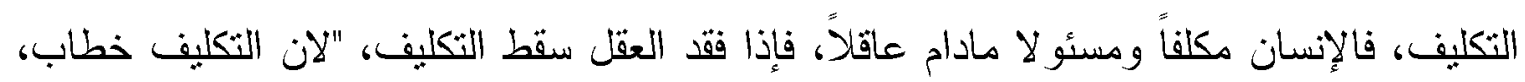
وخطاب من لا عقل له و لا فهم محال كالجماد و البهيمة"(i). (8) اهتم علماء الأصول بيان ذلك في كتبه في مباحث، التكليف، وشروط التكليف،وشروط المكلف به، أحكام التكليف.

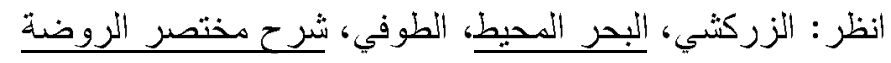

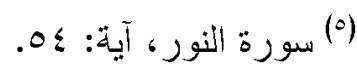

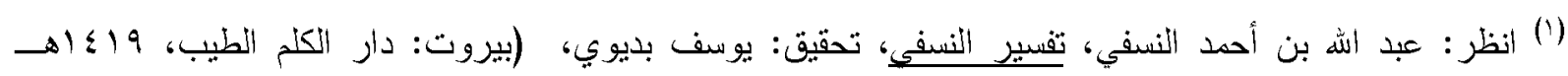

$$
\begin{aligned}
& \text {.010/4، (1991 = }
\end{aligned}
$$

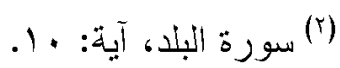

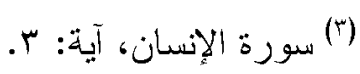

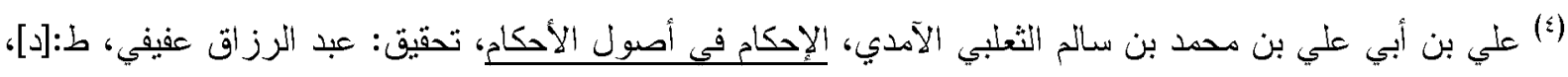

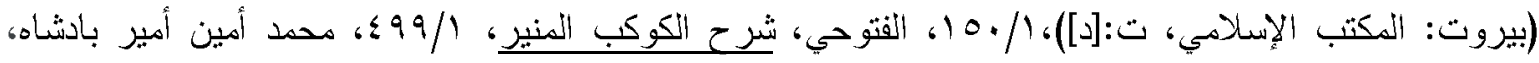

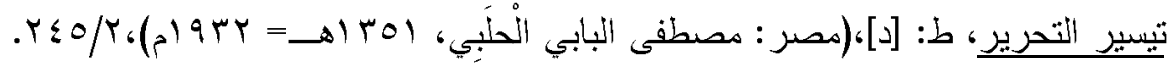


ومباحث الأهلية من أهم المباحث الأصولية، الثي ترثبط بالتكليف، فلا نكليف بغير أهلية، و لا

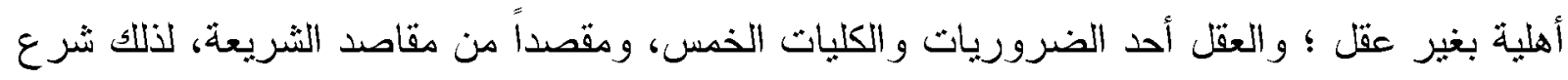

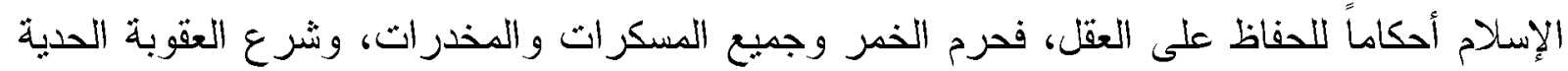
لثرب الخمر، وجعل طلب العلم فريضة لقوله صلى الله عليه وسلم "طلب العلم فريضة" (1)، فبالعقل

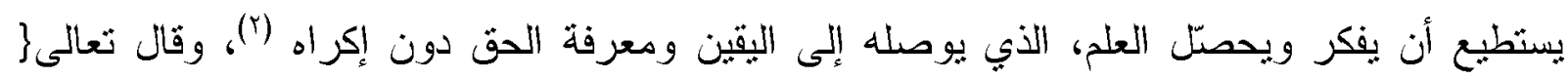

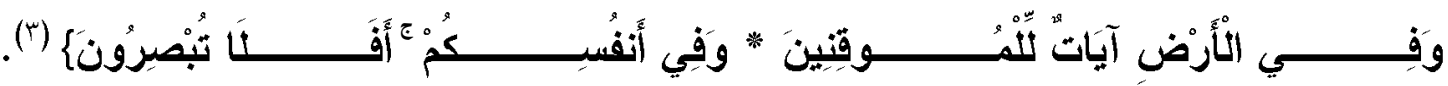

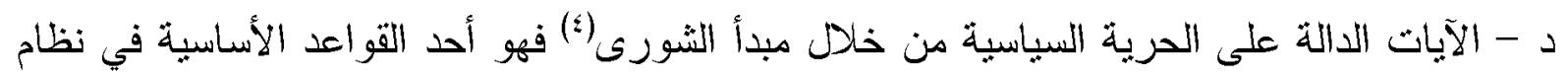

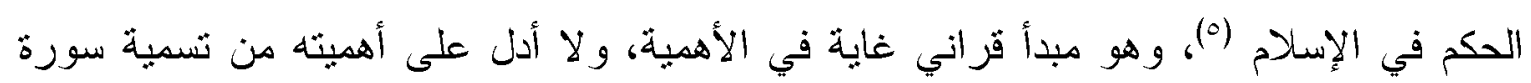

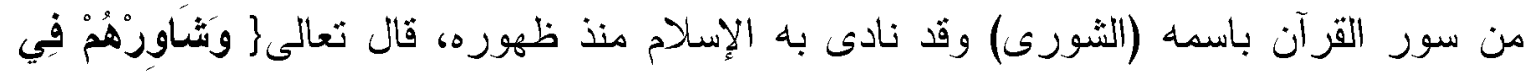

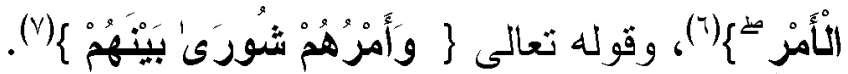

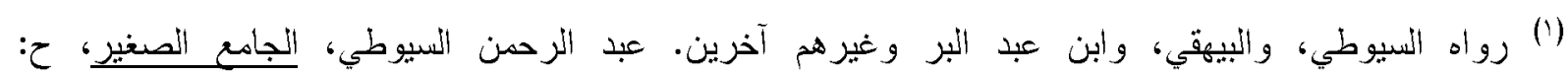

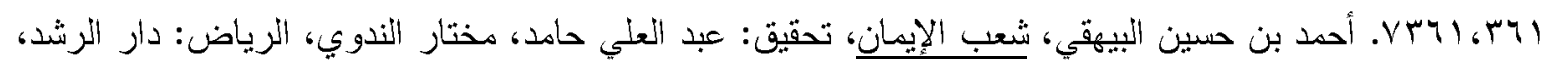

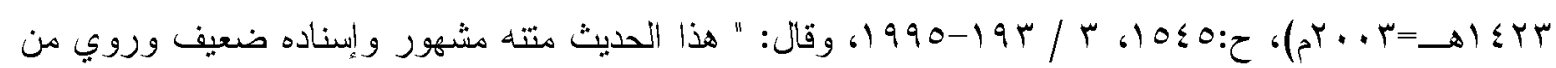

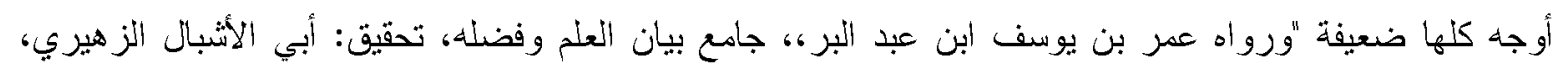

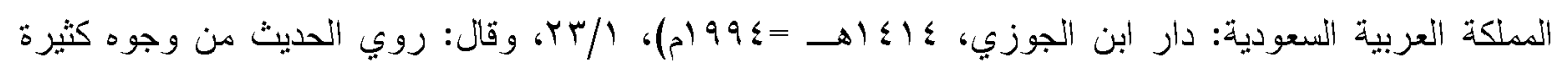

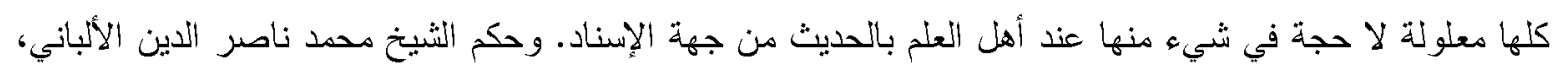

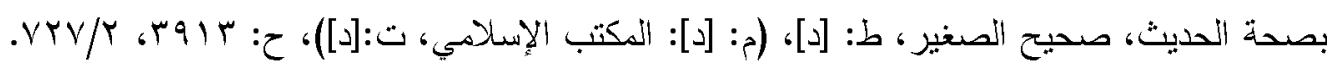

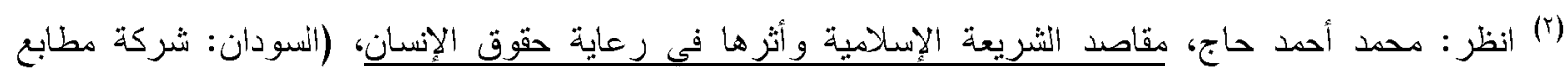

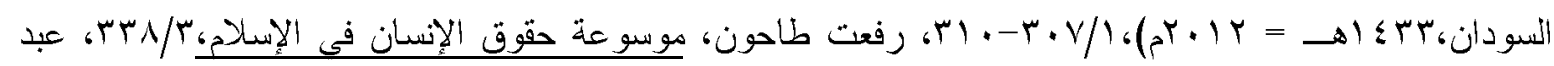

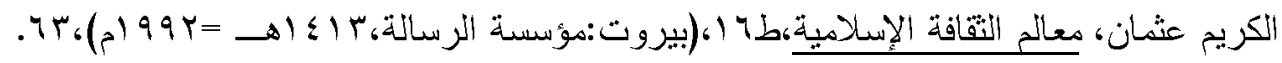

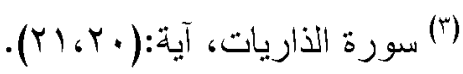

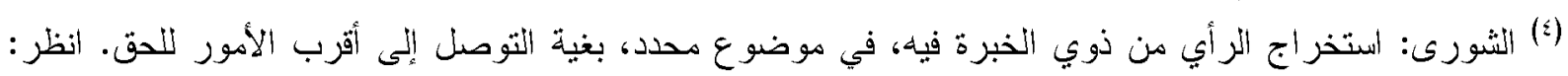

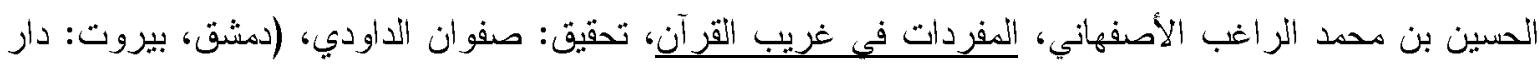

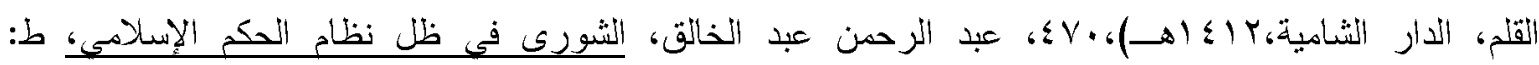

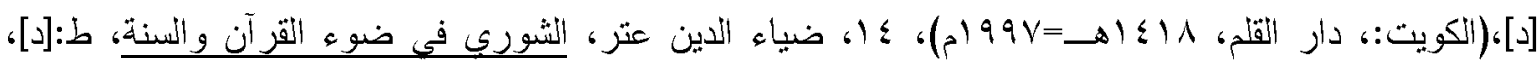

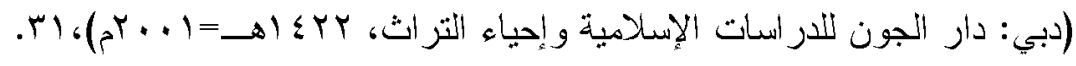

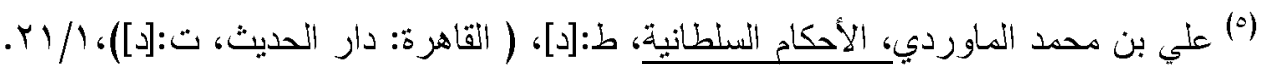
(T) سورة آل عمر ان، أية: 109.

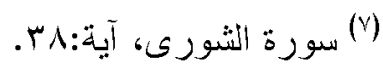


فحين يندبرون أمرهم بالثورى، و لا ينفرد أحدهم بالرأي، فأهم يؤكدون على النزعة الجماعية في

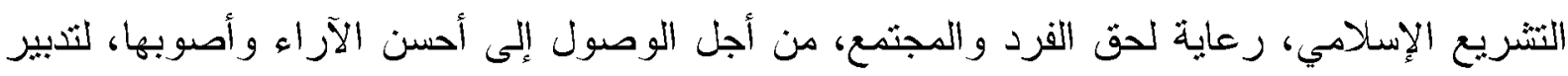

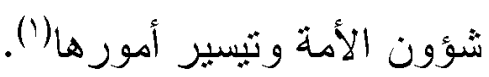

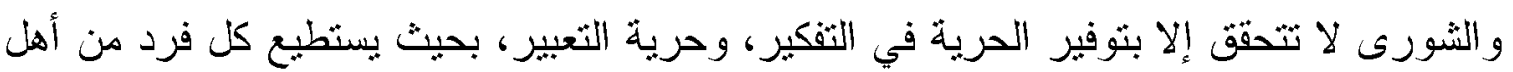

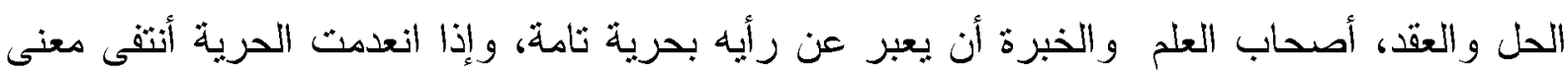

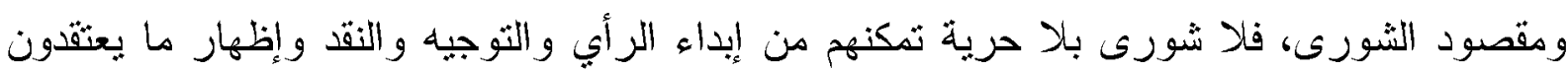
صو ابه.

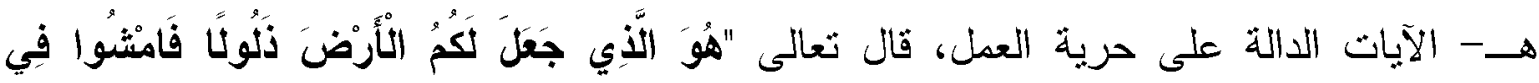

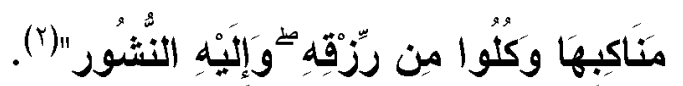
حث الإسلام العمل، حتى لا يككن الإنسان عالة على الآخرين، وكلل للفرد حرية العمل واختبار

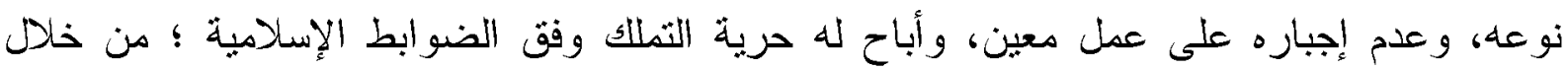
السعي في مناكب الأرض ؛ لتحصيل المال باعتباره من الضروريات الثي لا نستثيم مصالح الإنسان

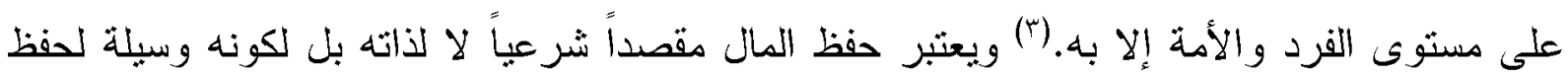

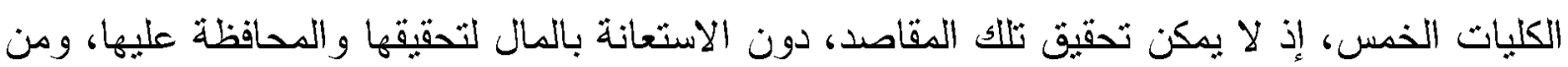

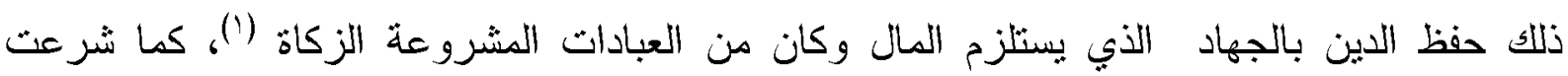

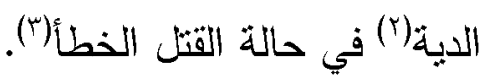
ثانياً: أصول الحرية في السنة النبوية:

(1) انظر: راوية بن احمد الظهار، حقوق الإنسان فى الإسلام، طب، (المدينة المنورة: دار الزمان،

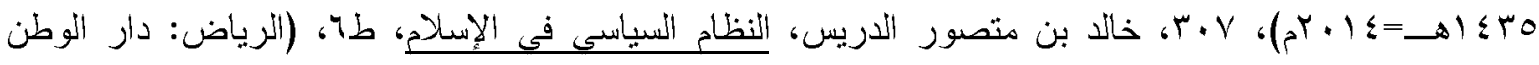

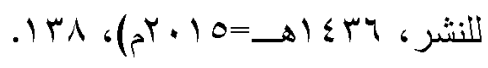
(r) سورة الملآك، آية: 10 (1)

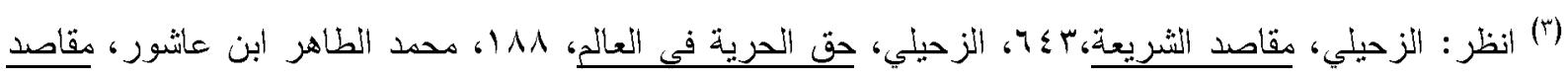

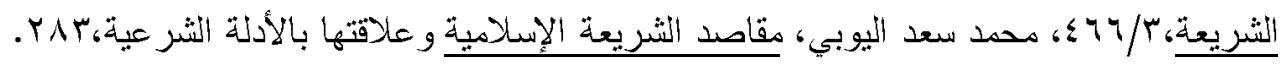

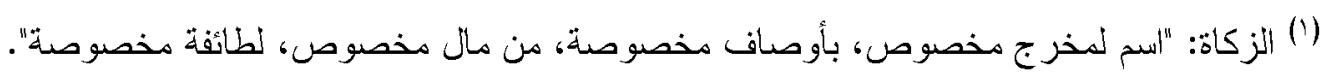

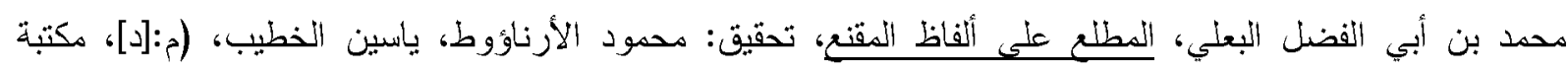

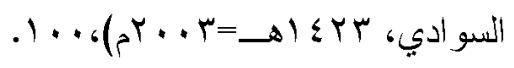

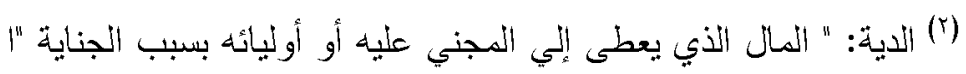
نظر: البعلي، المطلع على ألفاظ المقنع، بـ؛؛ محمود عبد الرحمن عبد المنعم، معجم المصطلحات و الألفاظ الفقهية،

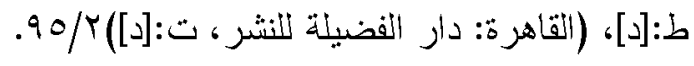
(") القتل الخطأ: أن برمي صيداً أو عرضاً، فيصيب أدمياً لم يقصده بالقتل. انظر : منصور بن يونس البهوتي، الروض

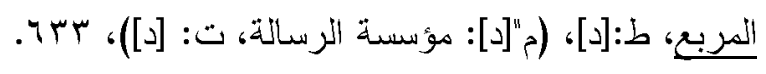


سعى الرسول عليه الصلاة والسلام إلى ثرسيخ وتوضيح مفاهيم وأسس الحرية من، فورد في

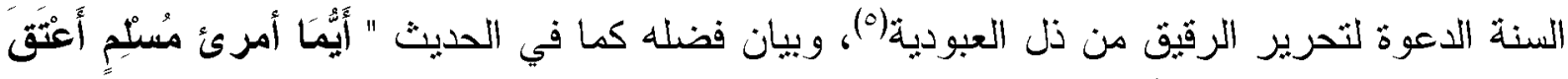

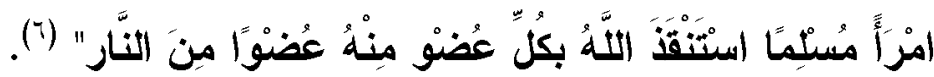

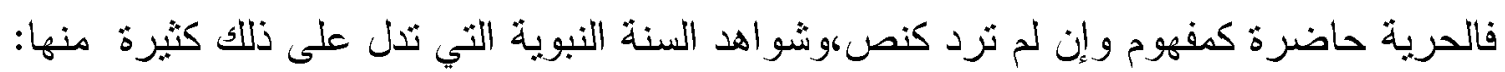

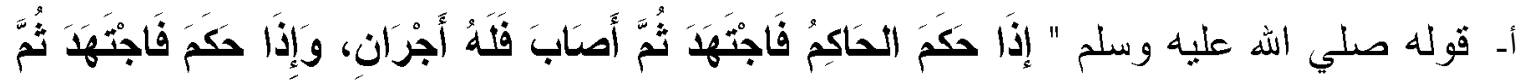

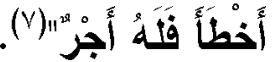

تعد حرية الرأي العمود الققري للحريات الفكرية، وقد أقر الإسلام هذه الحرية وكفلها في أوسع

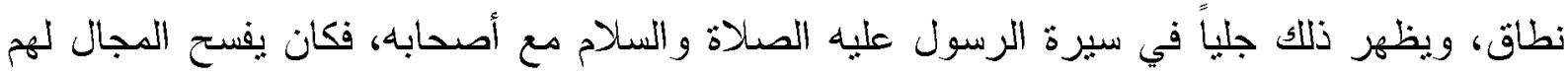

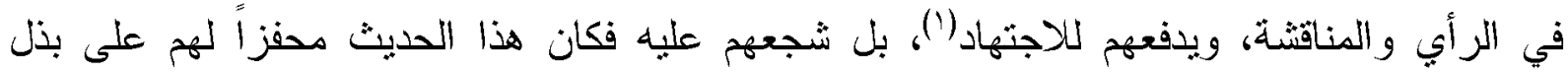

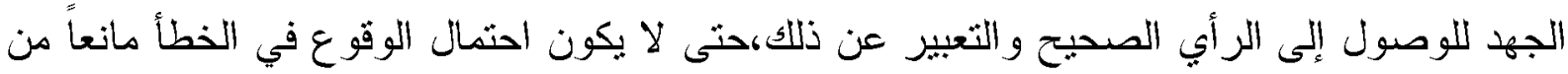

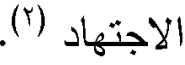

بل كان عليه الصلاة والسلام بحث الصدابة رضوان الله عليهم على الاجتهاد واستتباط الأحكام

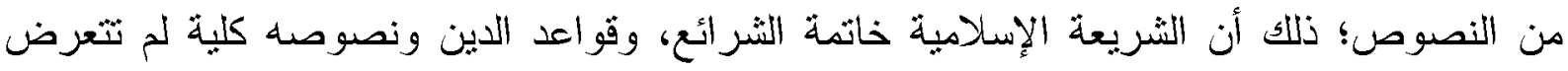

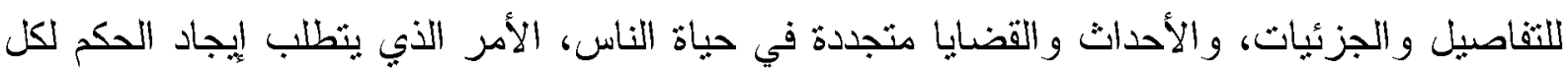

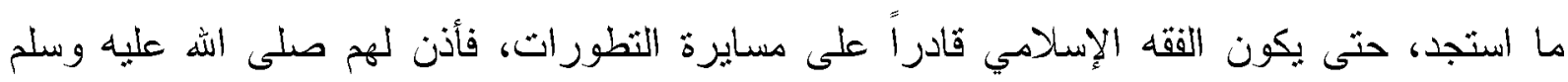

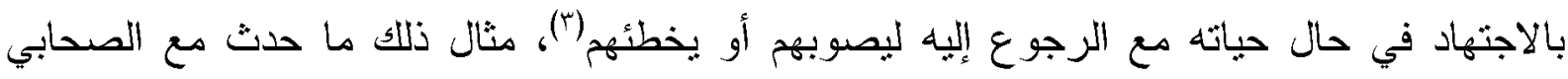

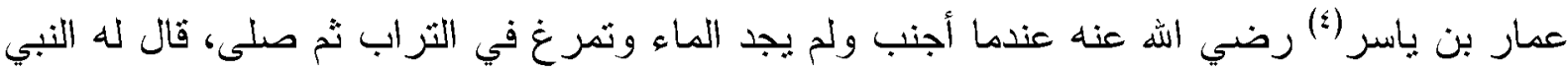

(1) لم يتم تتاول الحديث بصورة مفصلة لأنه خارج نطاق البحث.

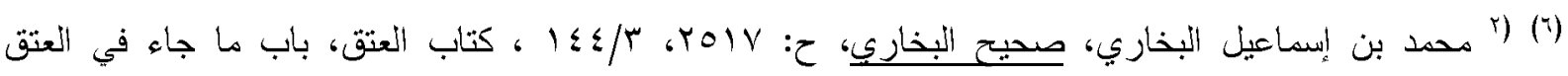
وفضله.

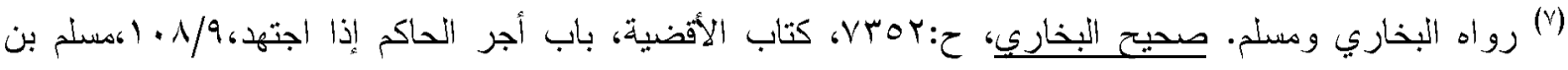

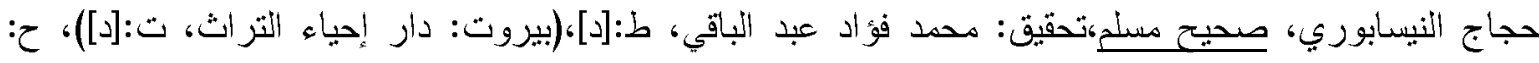

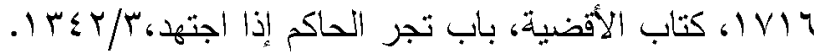

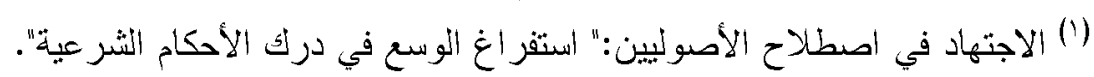

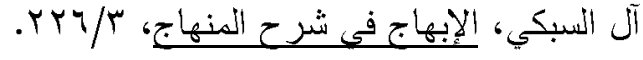

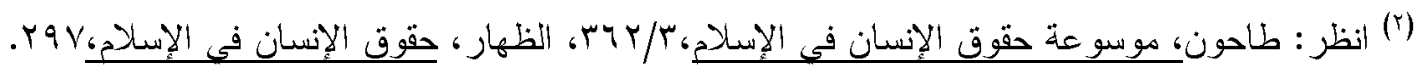

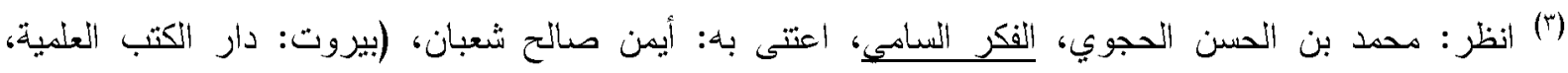

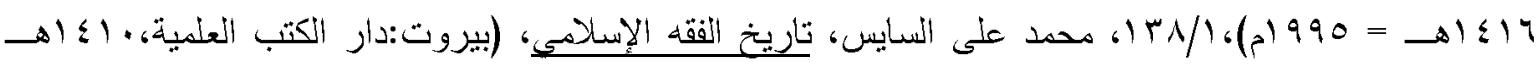

$$
.51 ،(م) 99 .=
$$

(§) عمار بن ياسر بن كنانة بن مالك العنسي، أبو اليقضدان، حليف بني مخزوم، كان من السابقين الأولين في الإسلام هو

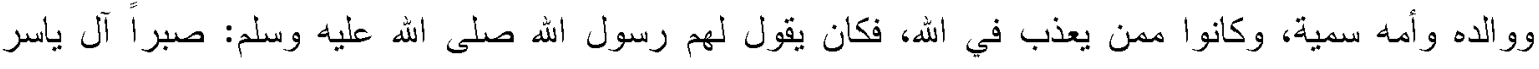


صلى الله عليه وسلم: "إنما كان يكفيك أن تقول هكنا وضرب بيديه إلى الأرض. فنفض يديه فمسح وجهه وكفيه" (0).

وقال النبي صلى الله عليه وسلم بوم الأحزاب:" لا يصلين أحد العصر إلا في بني قريظة، فأدرك

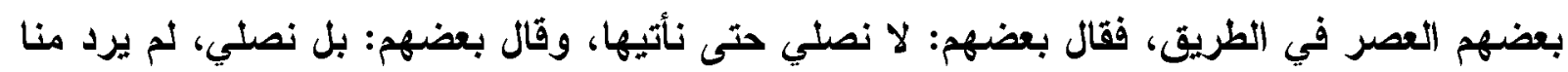

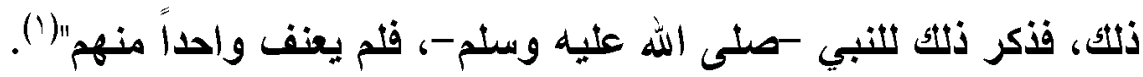

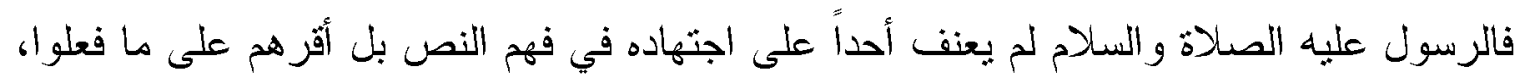

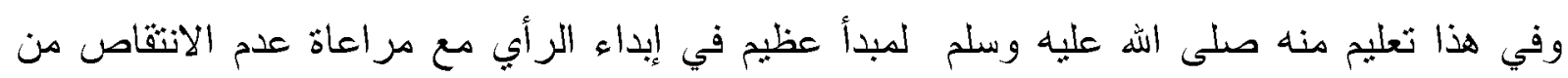

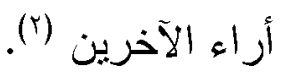
أما بعد وفاته عليه الصلاة والسلام أصبح الاجتهاد ضرورة تثريعية لإيجاد الحكم الثرعي لكل

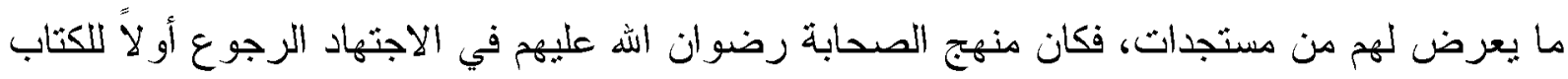

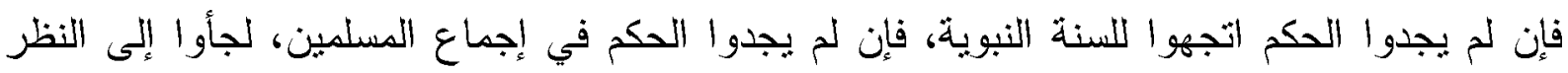
و الاجتهاد بآرائهم وأفهامهم وأعملوا عقولهم لإدراك الحكم الثرعي وإلحاق الأمور بأنشباهها، تحقيقاً للحاجات ورعاية للمصالح في ضوء مقاصد الثريعة وقو اعدها وأصولها ومبادئها (ّان.

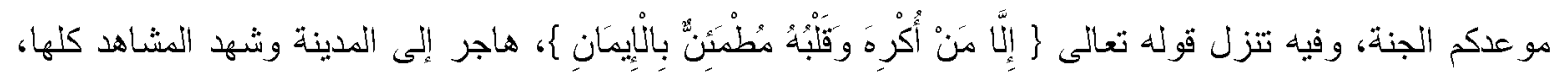

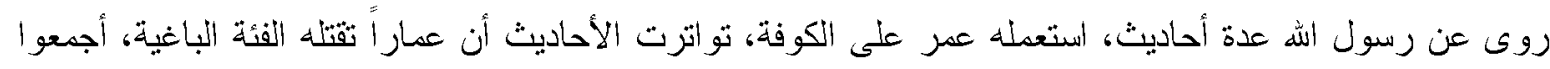

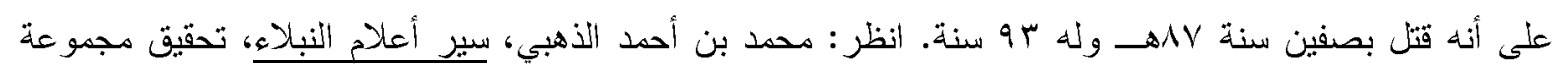

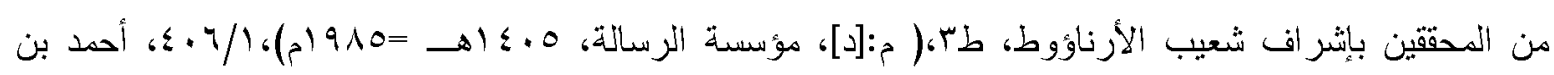

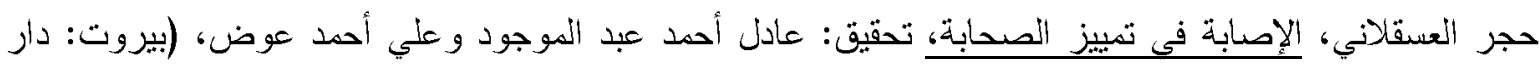

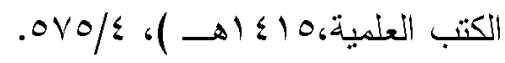

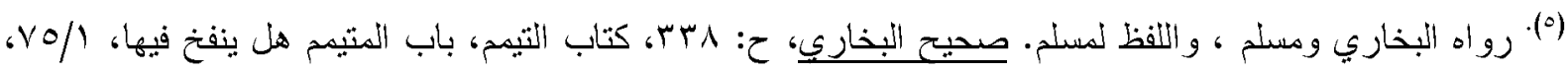

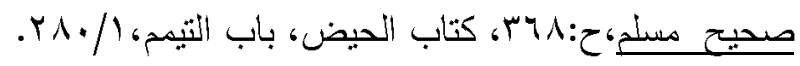

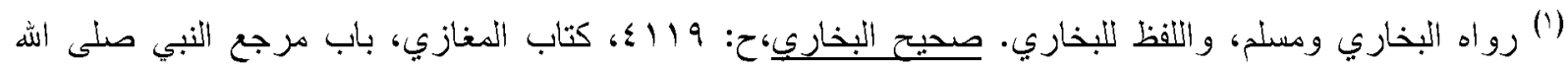

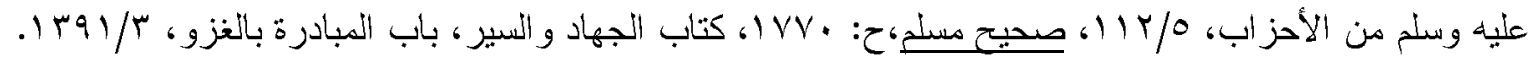

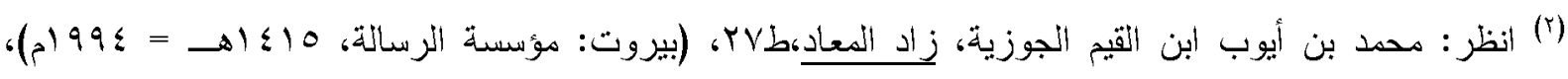
$.111 / r$

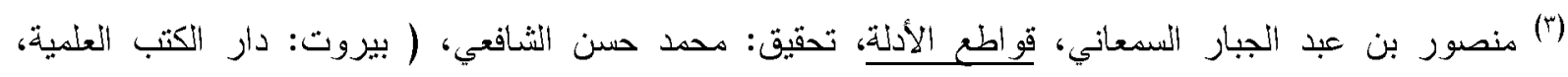

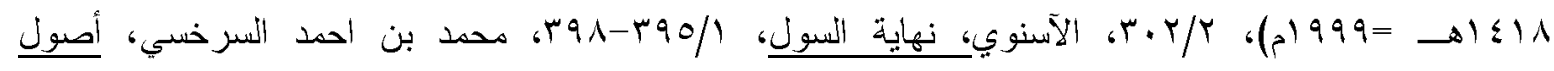

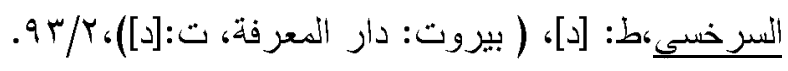


مثال ذلك: حديث معاذ (أرضي الله عنه أن رسول الله صلى الله عليه وسلم لما أراد أن بيعث معاذا إلى اليمن قال: " كيف تقضي إذا عرض لك قضاء؟ قال: أقضى بكتاب الله. قال فإن لم تجد في كتاب الله قال فبسنة رسول الله صلى الله عليه وسلم. قال فإن لم تجد في سنة رسول الله صلى الله عليه وسلم ولا في كتاب الله؟ قال أجته رأي ولا آلو؟ فضرب رسول الله صلّى الله عليه وسلّم صدره

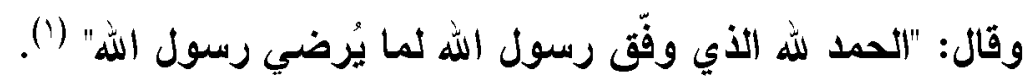
ب- إقامة العدل هو أحد مقاصد الثريعة(r) وحتى يتحقق العدل كفل الإسلام للفرد حرية الثقاضي لهي و التحاكم للثربعة الإسلامية ومن ذلك قصة الصحابية خولة بنت حكيم (؟)، لما حكم الرسول علية الصلاة والسلام في قضية شقاقها مع زوجها، بشان ظهاره(؛)، وكان الظهار قبل الإسلام

(ء) معاذ بن جبل بن عمرو بن أوس الخزرجي الأنصداري، أبو عبد الرحمن، أسلخ وهو ابن ثماني عشر، وشهد بدراً

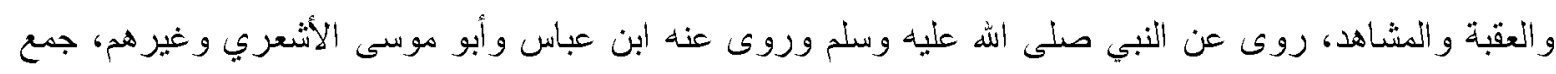

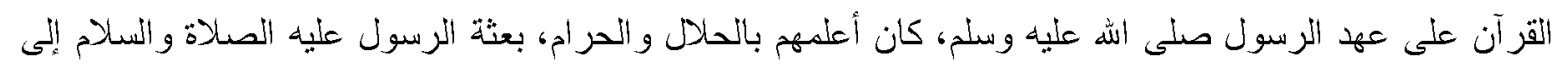

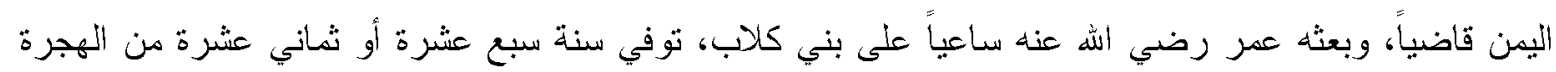
في طاعون عمو اس وهو ابن ثمان وتثلاثون.

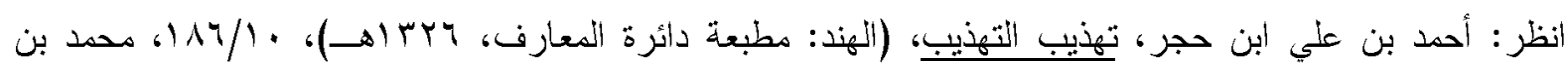

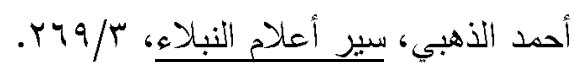

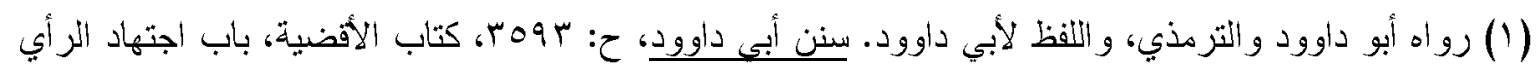

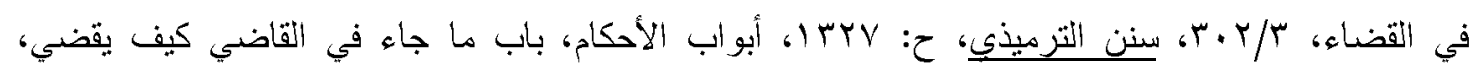

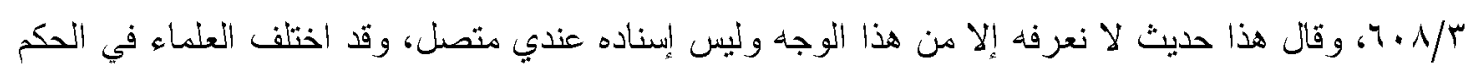

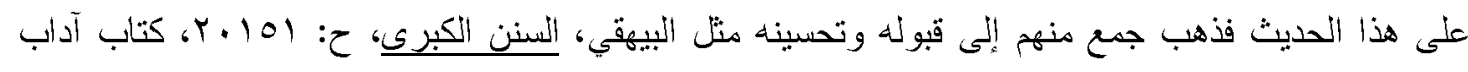

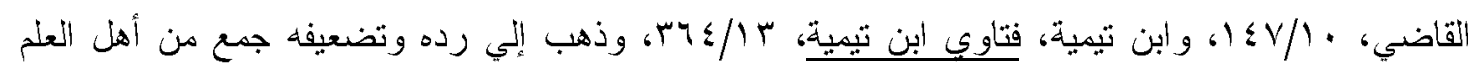

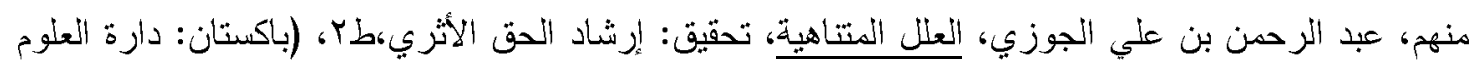

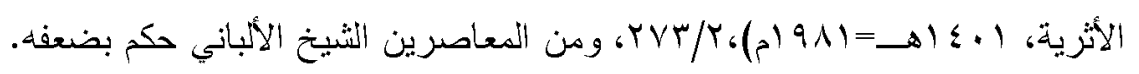

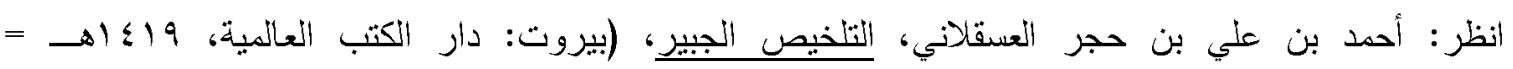

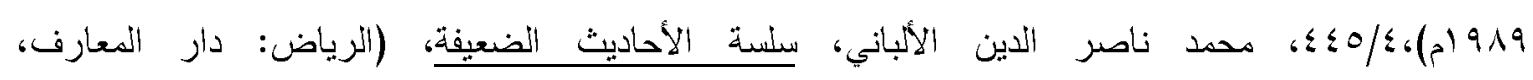
$r V \leqslant / r ،(م) 99 r=\rightarrow) \leqslant 1 r$

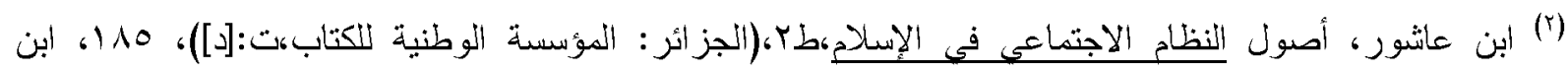

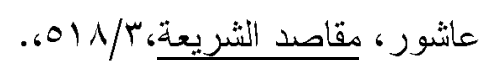

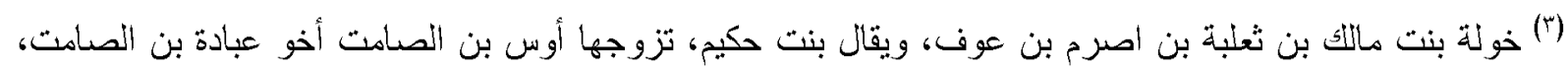
وهي المجادلة، أسلمت وبايعت رسول الله صلى الله عليه وسلم.

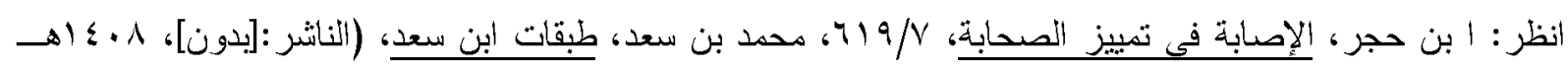

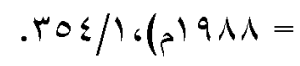
(؛) الظهار : "هو قول الرجل لامر أته أنت علي كظهز أمي"، الزركشي، شرح الزركثى على مختصر الخرقي،VN/O؛. 
طلاقاً، وعادت خولة تحاور الرسول علبه الصلاة والسلام وتجادله طلباً لمخرج لها من مصيبثها وقد قالت:" إلى الله أثنكو أمري وأمر مصيبتي " فنزلت الآيات الثي نتاولت حكم الظهار في سورة المجادلة|(1). سمح لها الرسول علبه الصلاة والسلام بالمناقتشة ولم ينهر ها عن الثقاضي لان الإسلام كفل لها

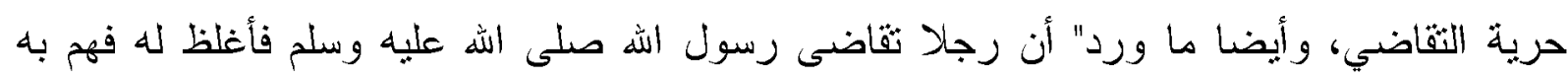

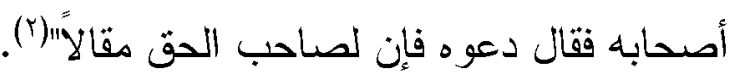

الخاتمة:

بعد عرض الباحثة لمفهوم الحرية وأصولها في ضوء القرآن الكريم والسنة النبوية، فقد ثوصلت لأن

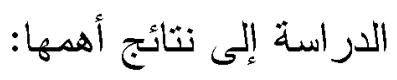
ا- أن الحربة شيء مقس في الإسلام لأن ذلك نابع من تكريم الهه للإنسان، بل من عبودية الإنسان

$$
\text { لله حيث يتحرر من كل شيء فهو "العبد الحر". }
$$

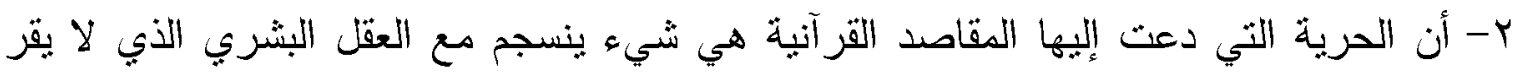
إجبار إنسان على أي دين.

ب- تعتبر الثُورى احدى القواعد الأساسية في نظام الحكم ، فهي نأكد على النزعة الجماعية في

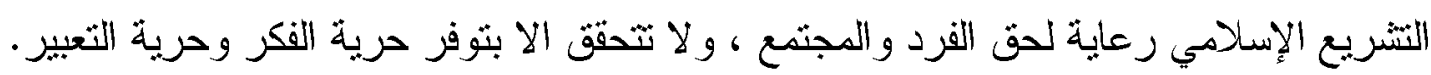

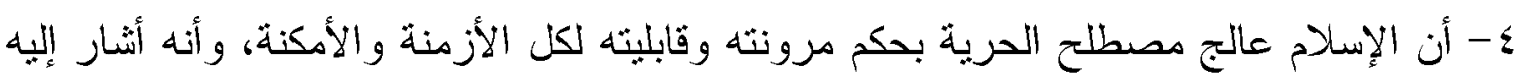

$$
\text { في كثبر من نصوص الكتاب و السنة. }
$$

ه- كقل الإسلام حرية ابداء الرأي والاجتهاد منذ فجر الدعوة ، فقد شجع الرسول عليه الصلاة

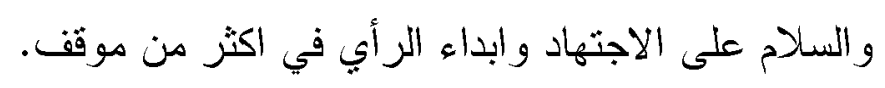

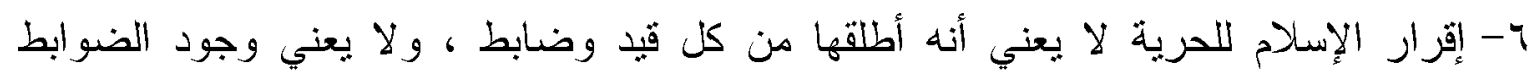

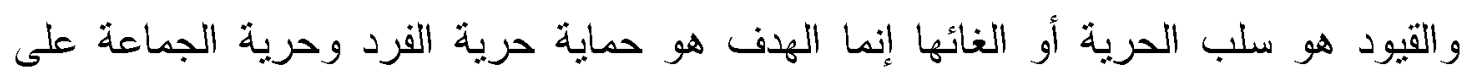

\section{تو ازن بينهما.}

V- المبادئ الإسلامية لها صفة الإلزامية الدينية والقانونية، وإن المؤمن خاضع لهذين النظامين،

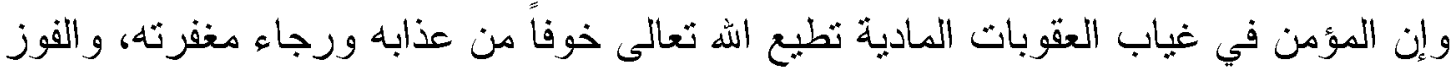

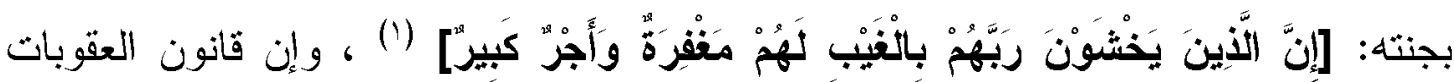

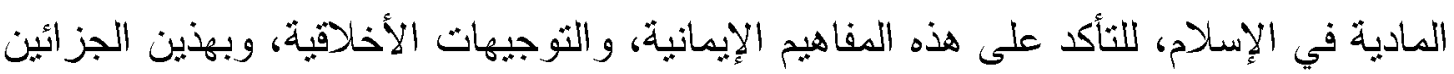

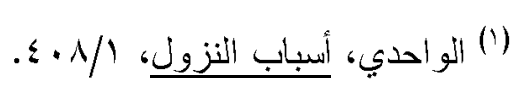

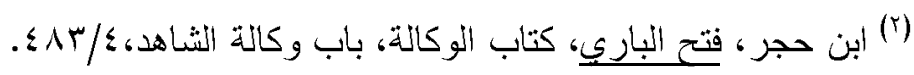


يصبح الإنسان، إنساناً سوياً مستقيماً، وأساساً لمجتمع أمين وسليم ومطمئن، وإن قوانين

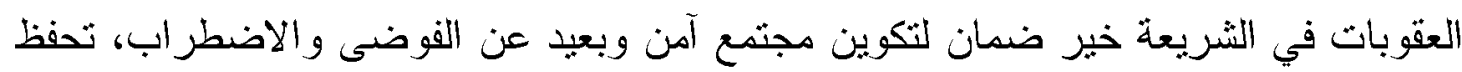

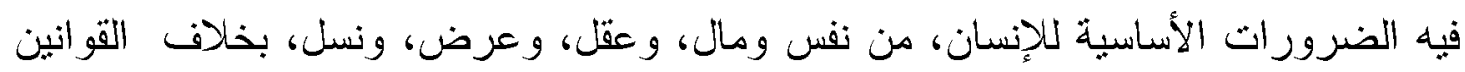

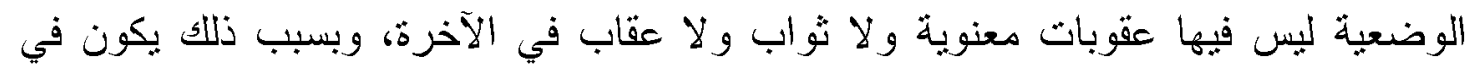

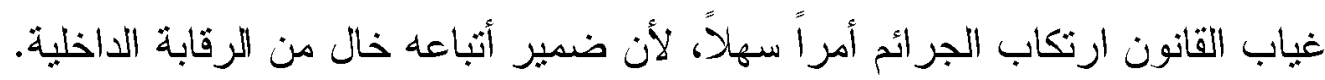

\section{المصادر والمر اجع}

اــ القر آن الكريم.

r- إبراهيم بن موسى بن محمد اللخمي الغرناطي الثهير بالثناطبي، الموافقات، نحقيق: أبو عبيدة

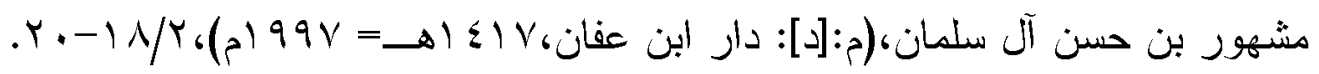

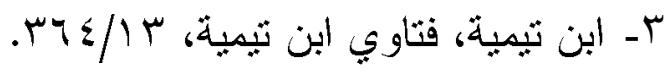

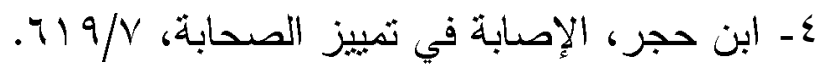

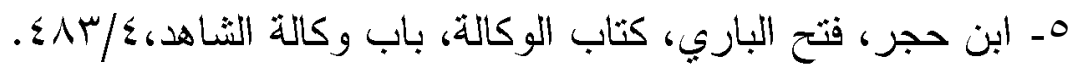

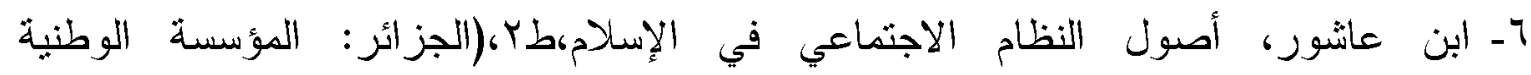

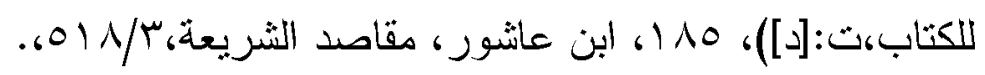

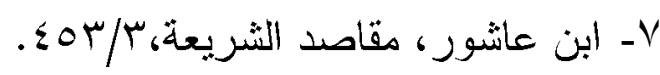

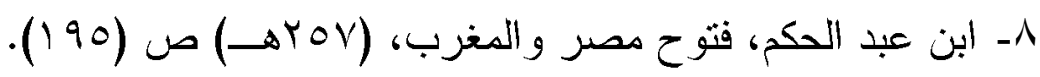

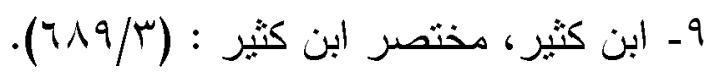

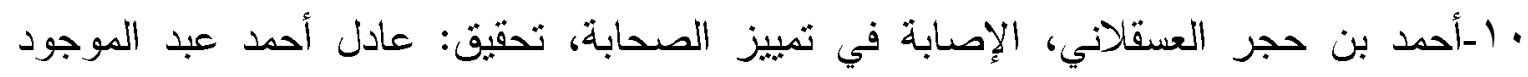

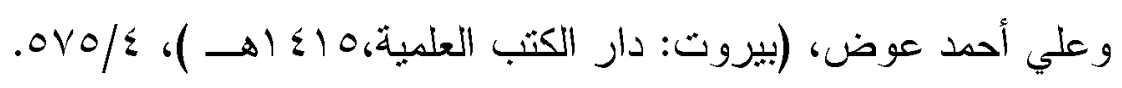

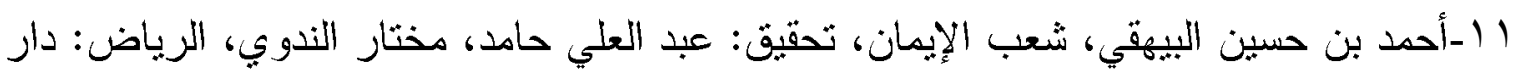
الرشد، سr أهـ

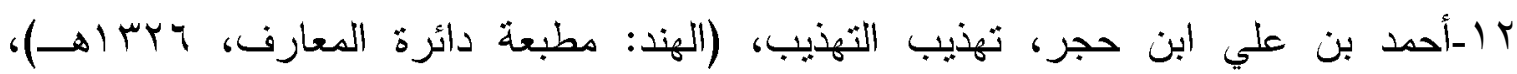
$.1 \wedge T / 1$.

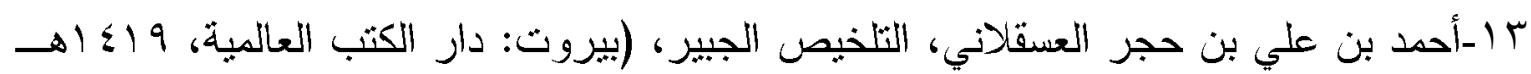
. $\Sigma \leqslant 0 / \Sigma ،(م) 919=$

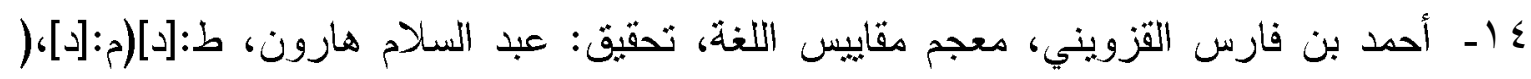

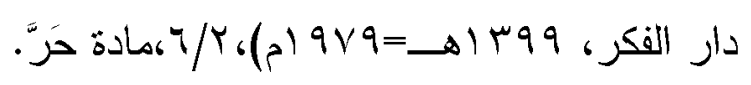

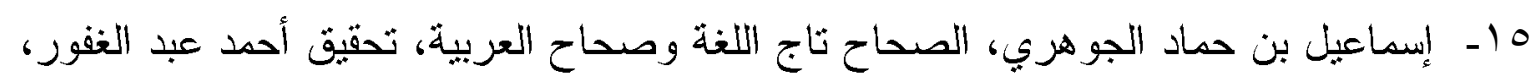

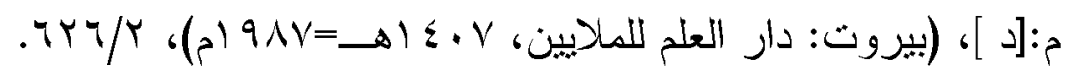

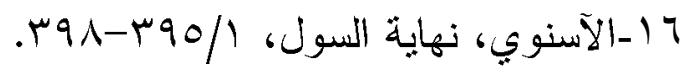




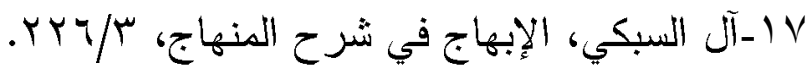

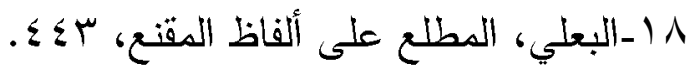

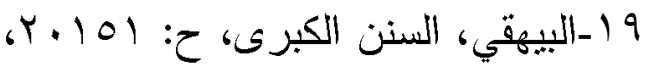
•r-التزرمذي، سنن الترميذي، ح: بوهب، أبواب الأحكام، باب ما جاء في القاضي كيف يقضي،

$$
\therefore \cdot \Lambda / r
$$

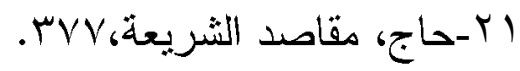

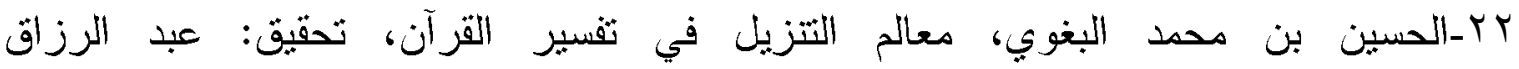

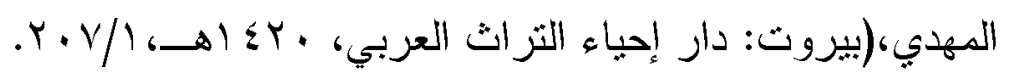

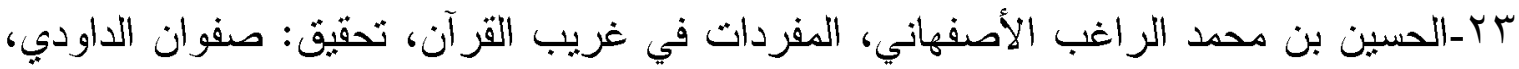

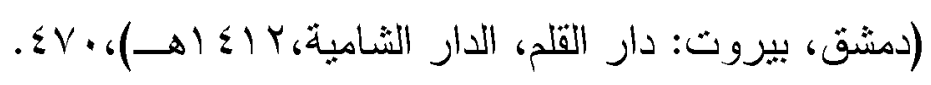

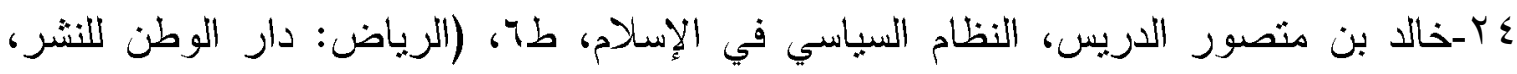

$$
\text { Tr }
$$

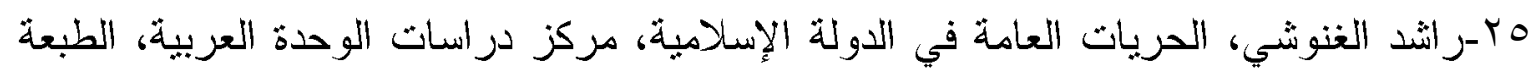

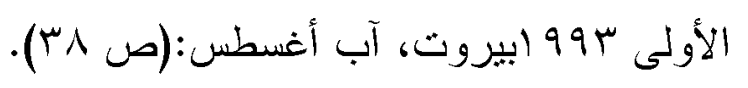

جr-راوية بن احمد الظهار، حقوق الإنسان في الإسلام، طج، (الددينة المنورة: دار الزمان،

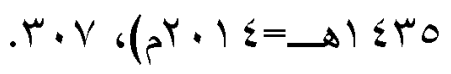

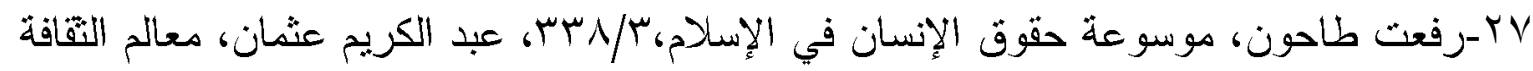

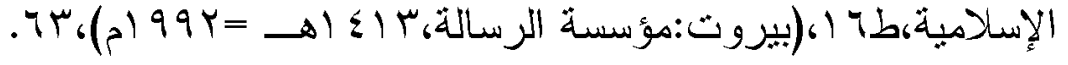

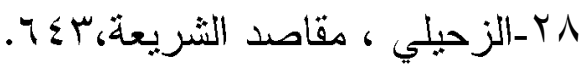

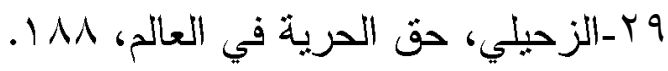

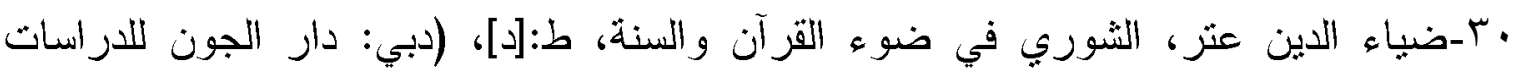

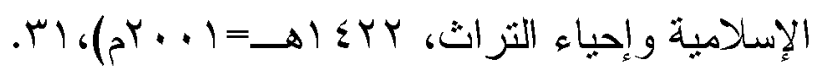

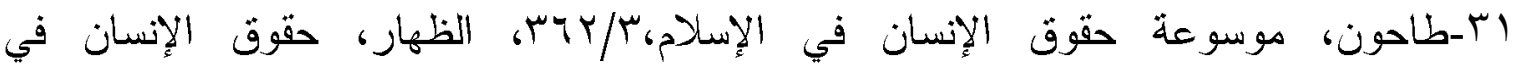

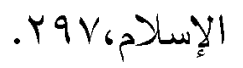

r r-عبد الرحمن بن علي الجوزي، العلل المتتاهية، تحقيق: إرشاد الحق الأثري،طوب، (باكستان:

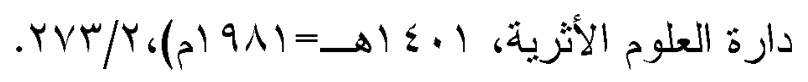

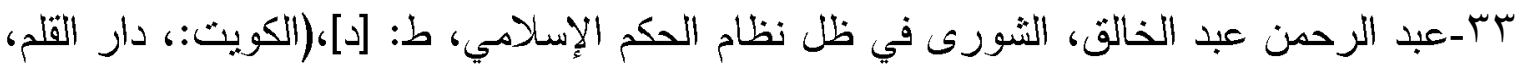

$$
\text { .) } \leqslant \text { ، (م) } 99 \vee=\rightarrow) \leq 11
$$

ع ז-عبد اله بن أحمد النسفي، تفسير النسفي، تحقيق: يوسف بديوي، (بيروت: دار الكلم الطيب،

$$
.010 / r \text { ، (م) (991 = } \rightarrow 1519
$$




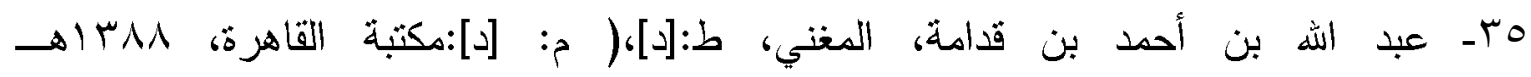

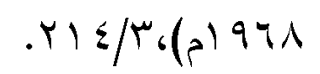

דr-عبد المجيد النجار، مقاصد الثربعة بأبعاد جديدةطץ، (بيروث: دار الغرب

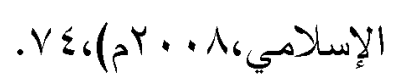

VTr- علاء الدين أبو بكر الكاساني، بدائع الصنائع في نزثيب الثرائع، طب،(م:[د]: دار الكتب

$$
\begin{aligned}
& \text { العلمية، } 7 \text { أهـ }
\end{aligned}
$$

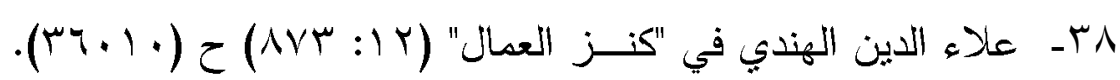

وس-على المؤمن، النظام السياسي الإسلامي الحديث و إثكالية الاقتباس من الأنظمة الوضعية، دار

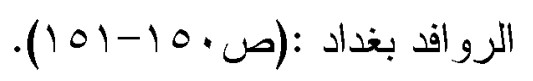

• ع-علي بن أبي علي بن محمد بن سالم الثعلبي الآمدي، الإحكام في أصول الأحكام، تحقيق: عبد

$$
\text { الرزاق عفيفي، ط:[د]، (بيروت: المكتب الإسلامي، ث:[د])، / / 10 1. }
$$

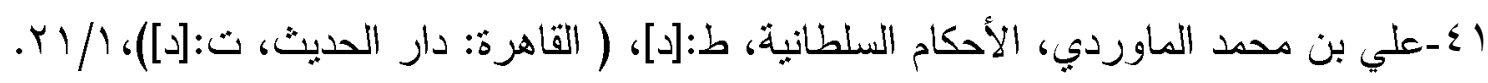

بع-علي بن محمد بن محمد بن حبيب البصري، الثهير بالماوردي، الحاوي الكبير، نحقيق: علي

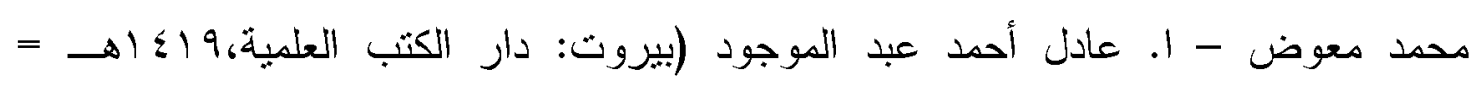

$$
.10 \mu / \mu_{6}(5) 999
$$

بع-عمر بن يوسف ابن عبد البر، جامع بيان العلم وفضله، تحقيق: أبي الأشبال الزهيري، المملكة

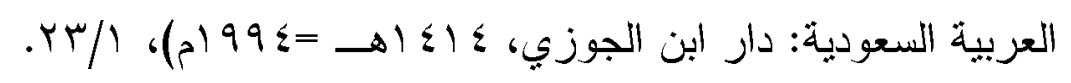

ع ع-فتحي الدريني، خصائص التسريع الإسلامي في السباسة والحكم، طب، ( بيروث: مؤسسة

$$
\text { الرسالة، ع }
$$

0ـ- الفتوحي، شرح الكوكب المنير، 99/1، محمد أمين أمير بادشاه، ثيسير التحريز، ط:[د]،(مصر : مصطفى البابي الْحلَبِي، 1 أهـ جـ-ماجد أحمد مومني، حقوق الإنسان في الإسلام، صع 9. V V-محمد أحمد حاج، مقاصد الثريعة الإسلامية وأثرها في رعاية حقوق الإنسان، (السودان:

$$
\text { شركة مطابع السودان،سrع (هـ }
$$

^ع-محمد الطاهر ابن عاشور، أصول النظام الاجثماعي، طب،(م:[د]، الثركة الثونسية للتوزيع،

$$
.10 \cdot 6(5) 910
$$

وع-محمد الطاهر ابن عاثتور، التحرير و التتوير، ط:[د]، (تونس: الدار التونسبة للنشر، عدو (م)،

$$
.109-101 / 0
$$

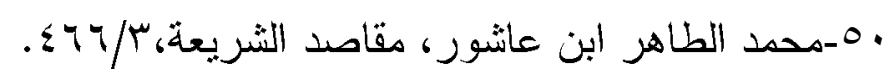


10-محمد بن أبي الفضل البعلي، المطلع على ألفاظ المقنع، تحقيق: محمود الأرناؤوط، ياسين

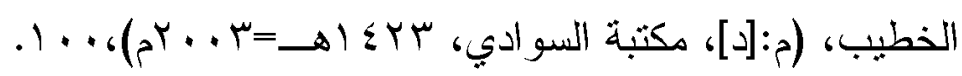

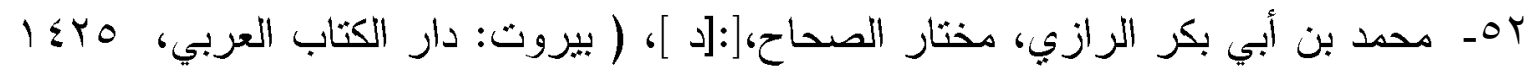

$$
\text { . (ب) }
$$

بهـمحد بن أحمد الذهبي، سير أعلام النبلاء، نحقيق مجموعة من المحققين بإنشراف شعيب

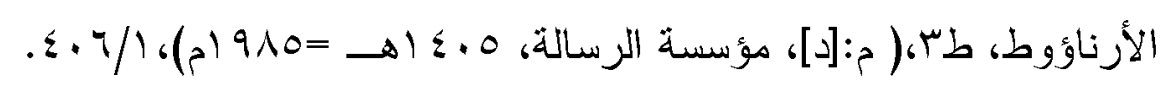

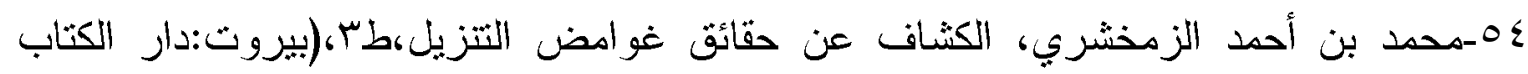

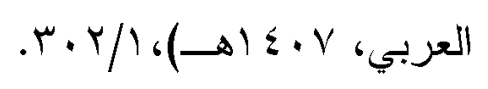

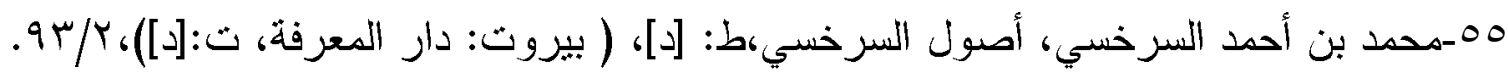

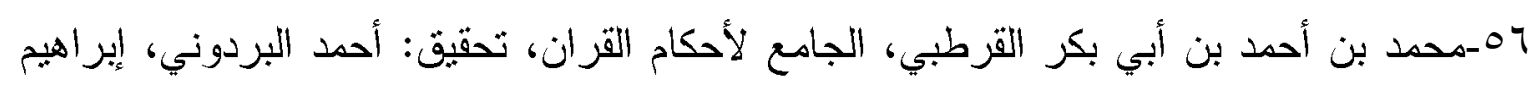

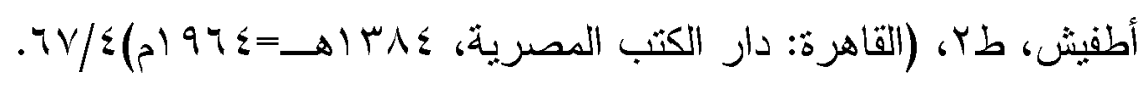

V_ov

$$
\text { دار الحدبث، }
$$

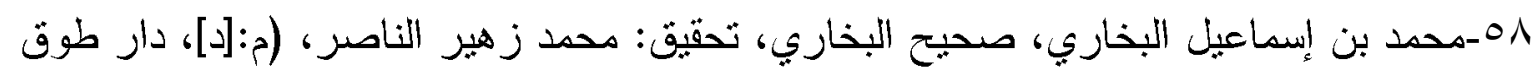

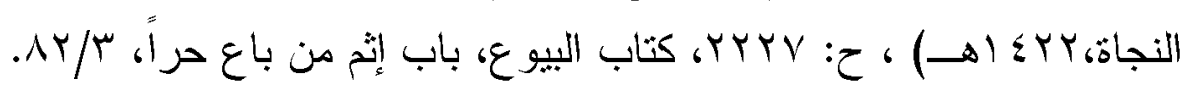

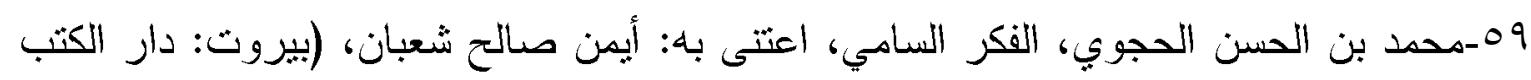

$$
\text { العلمبة، } 191 \text { أه }
$$

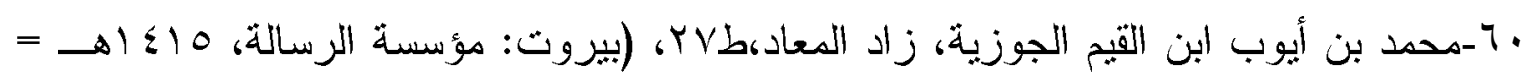

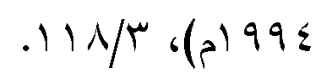

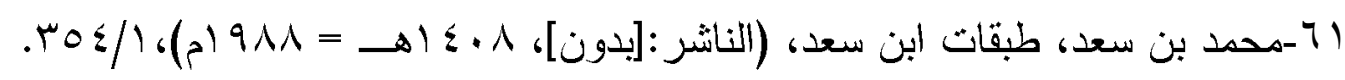

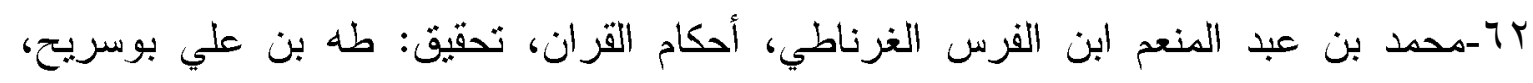

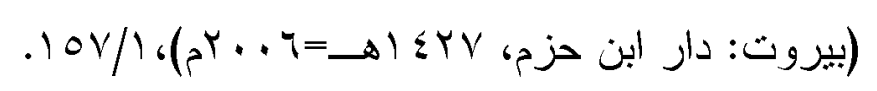

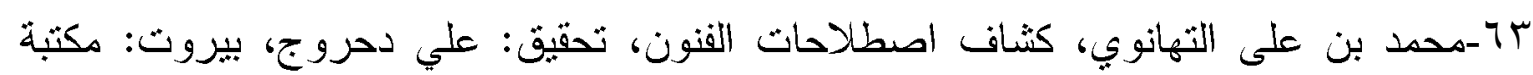

$$
\text { لبنان، }
$$

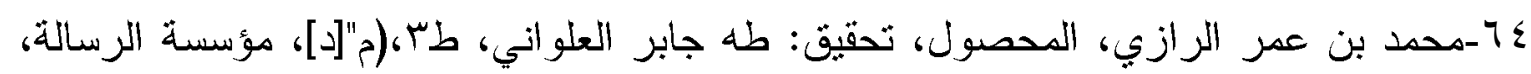

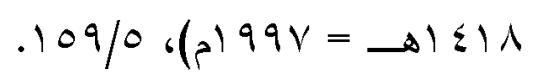

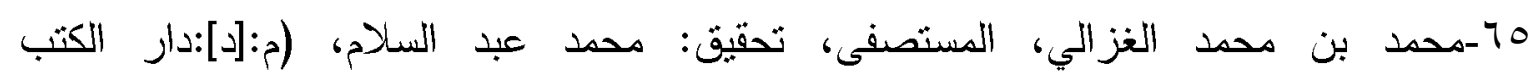

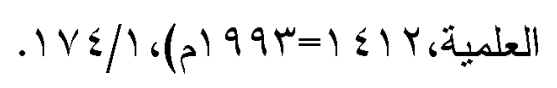

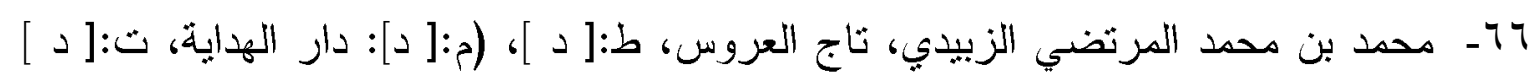

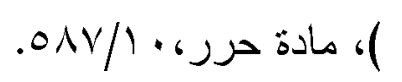




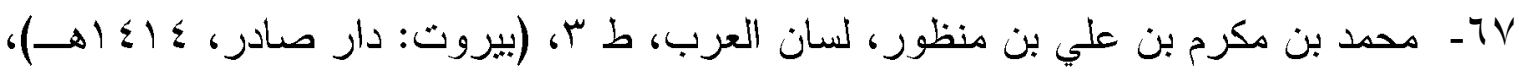
$.|\Lambda \varepsilon-| V V / \varepsilon$

1^-محمد سعد اليوبي، مقاصد الثريعة وعالقتها بالأدلة الثرعبة، (الرياض: دار الهجرة،

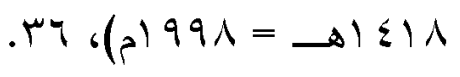

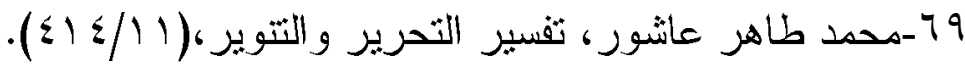

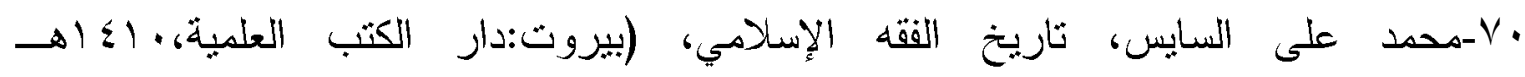
.5)، (م) $99 .=$

|V-محمد عمر فخر الدين الرازي، مفاتيح الغيب، طب،(بيروت: دار إحياء النراث

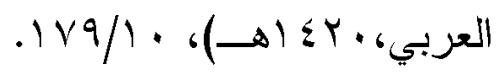

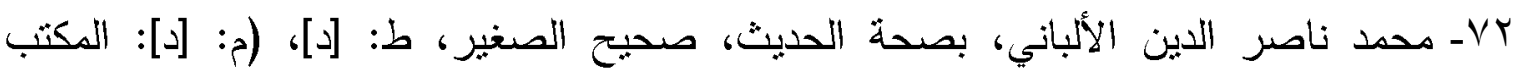

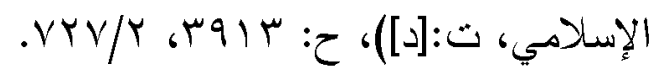

Tr-Vمحود بن عبد الله الألوسي، روح المعاني في تفسير القرآن، نحقيق: على عبد الباري عطية،

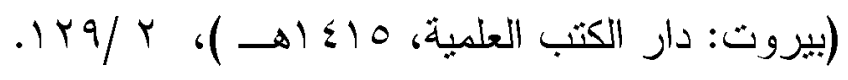

ع V-محمود عبد الرحمن عبد المنعم، معجم المصطلحات والألفاظ الفقهية، ط:[د]، (القاهرة: دار

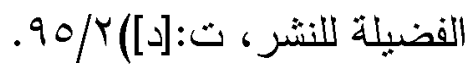

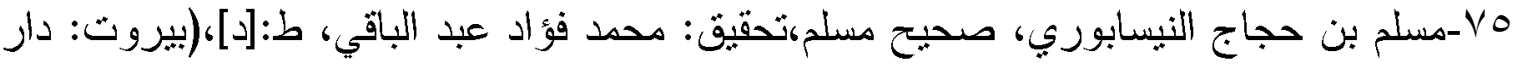

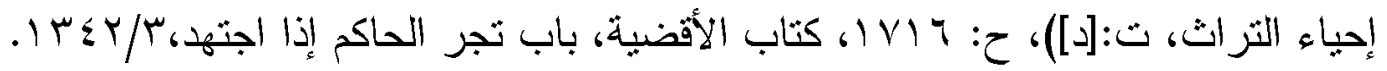

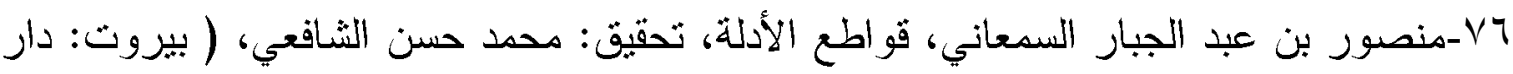

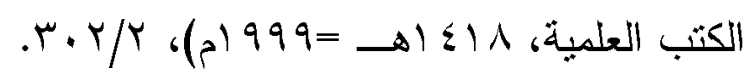

VVV-VV

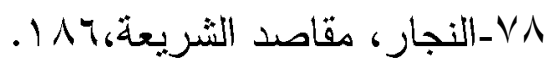

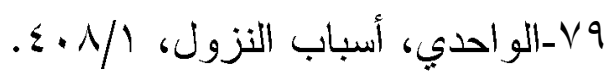

•^-وهبة الزحيلي، حق الحرية في العالم، دار الفكر المعاصر، بيروت لـبنان، الإعادة الثالثة

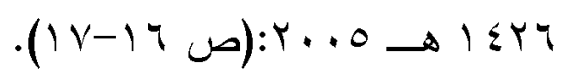

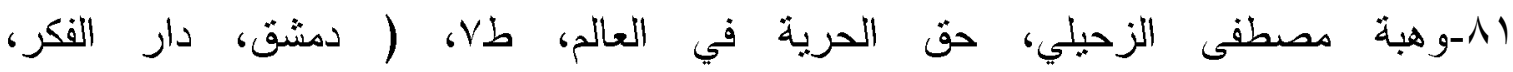

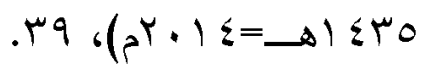

